\title{
Mobile Micro-X-ray Fluorescence Analysis (XRF) on Medieval Paintings
}

\author{
Christoph Herm*
}

\begin{abstract}
X-ray fluorescence has long been applied to objects of art and archaeology for non-destructive elemental analysis. When the object under investigation is either too big or too fragile to be moved a mobile instrument is needed which can be brought on site. A short overview of the development of techniques and applications shall be given in the paper. Then three case studies are reported in which ArtTax/Artax spectrographs were applied for the analysis of medieval paintings. Experimental issues are discussed with respect to the application to paintings as well.
\end{abstract}

Keywords: Art · Gilding · Painting $\cdot$ Pigment $\cdot$ X-ray fluorescence

\section{Introduction}

Non-destructive elemental analysis of objects of art and archaeology has long been a major task for analytical chemistry. Generally, the data characterizes the composition of inorganic substrates (e.g. ceramics, glass, metals) or gives hints on the inorganic colouring matter on the surface (pigments, metal leaves, mordants). X-ray fluorescence has long been applied to this task, both in energy-dispersive and wavelengthdispersive configurations. It is possible to generate characteristic X-ray emission by different excitation sources: X-ray tube, radionuclides, synchrotron radiation (XRF), and different kinds of accelerated ions (PIXE). Today, synchrotron X-rays offer high precision measurements and promise confocal, three-dimensional evaluation. ${ }^{[1,2]}$

When the object under investigation either is too big or too fragile to be moved, a mobile instrument is needed which can be

${ }^{*}$ Correspondence: Prof. Dr. C. Herm

Hochschule für Bildende Künste Dresden

Studiengang Restaurierung

POB 160156

D-01287 Dresden

E-mail: herm@serv1.hfbk-dresden.de brought on site. Although it is impossible to review the application of mobile XRF analysis to objects of art and archaeology in this context, a short overview of the development of techniques and applications shall be given here.

Mobile XRF spectrometers can be divided into portable, hand-held instruments and modular systems which consist of a measuring head and a remote control unit. Small portable instruments were initially based on radionuclide sources and are mainly designed for geological field surveys. More recently, the application of such an instrument to photographs was reported. ${ }^{[3]}$ An experimental setup based on radionuclide excitation sources $\left({ }^{109} \mathrm{Cd},{ }^{241} \mathrm{Am}\right)$ was applied to objects of art and archaeology. ${ }^{[4]}$ A trial application by the author of such an instrument to a panel painting indicated general suitability. ${ }^{[5]}$ Nevertheless, there were also drawbacks such as the restricted excitation energy ranges and scattered radiation depending on the source as well as the relatively big irradiation area of several millimetres in diameter. Since 2001 handheld XRF spectrometers based on X-ray tubes have appeared on the market. One instrument (Innov-X Systems) was evaluated for application to objects made of glass and metals and was found suitable for the detection of bulk elements in a semi-quantitative approach. ${ }^{[6]}$

Among the modular systems, the Spectrace 6000 from Tracor seems to have been frequently used. The laboratory of the Swiss Institute of Art Research (SIK/ISEA) in Zurich has successfully used such an instrument for many years. ${ }^{[7]}$ More recently, a commercial mobile micro-XRF system (Seiko SEA 200 Field-X) was applied to paintings as well as to polychrome and gilded sculptures in Japan. ${ }^{[8,9]}$ Its technical characteristics are a measuring head of ca. $5 \mathrm{~kg}$ weight which contains a small $\mathrm{Rh}$ $\mathrm{X}$-ray tube, an electrically cooled semiconductor detector and a colour CCD camera. The irradiation area is $2 \mathrm{~mm}$ or $5 \mathrm{~mm}$ in diameter.

In 2000 a mobile XRF system came on the market which was specifically designed for art objects. ${ }^{[10]}$ Initially named 'ArtTax', this systems is now offered as 'Artax'. Its technical characteristics are described in the experimental section. The first published application was the identification of inks in manuscripts ${ }^{[11]}$ and investigation of deterioration caused by those writing materials. ${ }^{[12]}$ Later, the studies were extended to coloured prints and drawings on paper ${ }^{[13,14]}$ and enamels. ${ }^{[15]}$ The application of the Artax system to easel paintings developed a few years later. ${ }^{[16]}$ The largest study of paintings was a survey of the pigment smalt covering a total of 70 paintings. ${ }^{[17]}$ Historic wall papers, similar to paintings but immobile, were also analyzed. ${ }^{[18]}$ Furthermore, Artax was employed to detect chlorine-containing pesticides in objects, ${ }^{[19]}$ following an earlier approach using a portable XRF. ${ }^{20]}$ Recently it appeared that an Artax has successfully been applied to a three-dimensional painted object in Switzerland. [21] A review of the capabilities and limits of this technique has appeared recently. ${ }^{[22]}$ Using this system, measurements on paintings are reported not to cause any visible damage, whereas light material such as glass or 
ceramics could show reversible discolouration due to lattice disorders caused by the X-rays. ${ }^{[22]}$

Besides the commercially available systems described above, experimental systems have been developed for the investigation of art objects: at the Academy of Fine Arts in Vienna a mobile XRF system was constructed which is dedicated to the analysis of objects of art. ${ }^{[23,24]}$ The published applications again are on works on paper. ${ }^{[25,26]}$ Experimental setups using different X-ray tubes and detectors were applied to frescoes and easel paintings in Italy[27] as well as to prehistoric murals in France.[28] Furthermore, a series of Perugino paintings were investigated using mobile XRF.[29] Mural paintings were investigated by another XRF spectrometer, where a polycapillary conic collimator (PCC) was used in front of the detector, which enabled the nature of the thickness of the layers to be studied as well. ${ }^{[30]}$ A Chinese group has developed a similar system which includes a polycapillary lens for the analysis of archaeological objects. ${ }^{[31]}$

The above literature survey illustrates that true mobile XRF is of growing importance for analysis in the field of archaeometry and technical art history. In this paper three case studies are reported in which ArtTax/Artax spectrographs were applied for the analysis of medieval paintings, both on textile and wood panel. It is only possible to present results for the pigments in this paper, whereas the painting techniques (support, preparation layers, binder of the paints, etc.) are described in the respective publications. Additionally, experimental issues are discussed with respect to the application to paintings.

\section{Results and Discussion}

\subsection{Case Study 1}

In addition to painting on wood panels, painting directly on canvas (without a ground layer) also seems to have been a common technique in the late middle ages. When aqueous binders are used for the paint, it is called 'distemper' ('Tempera' in German). This appears to be the case for most of the paintings, which are called 'Tüchlein' following an expression of the painter Albrecht Dürer. ${ }^{[32]}$ Because of their fragile composition only a few of these paintings have survived. For this kind of paintings interpretation of the elemental analytical data with respect to pigments was expected to be relatively straightforward because a Tüchlein is typically composed of only one pigmented layer. Furthermore, a relatively limited range of pigments, originating primarily from natural sources, was available for a painter in the period around 1500 .

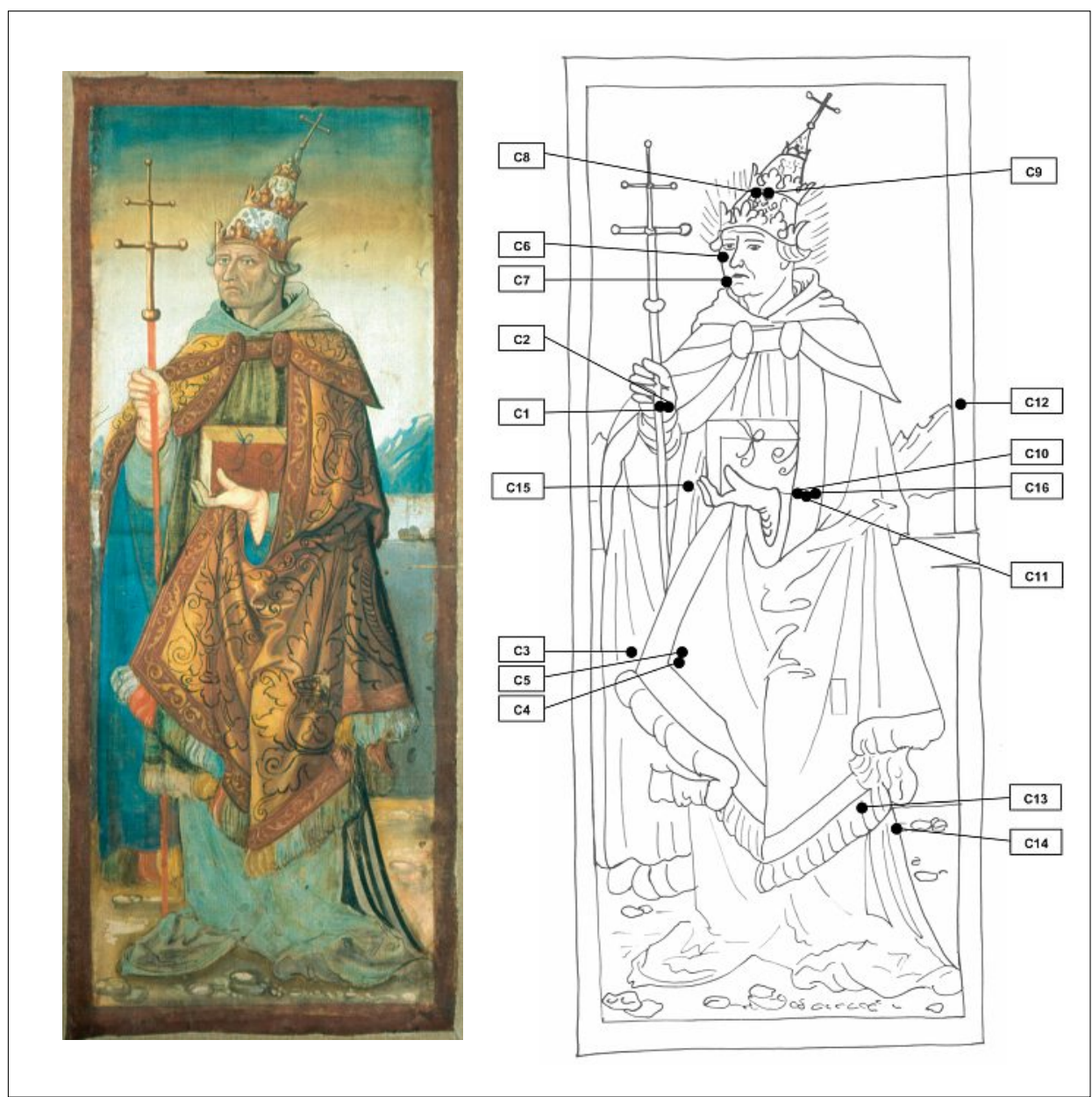

Fig. 1. Left: 'Saint Sixtus' from the 'Halberstädter Heiltumsschrank', ca. 1520, $131 \mathrm{~cm} \times 54 \mathrm{~cm}$, Halberstadt Domschatzsammlung. Photograph: Maria Petrasch: Right: micro-XRF measuring positions. Drawing: Maria Petrasch.

The 'Halberstädter Heiltumsschrank' is a large wooden trunk from around 1520 , used as a reliquary. It contained four 'Tüchlein' from the same time, which were investigated and restored within the framework of a diploma thesis. ${ }^{[33]}$ Both reliquary and paintings are on exhibition in the Domschatzsammlung in Halberstadt, Germany. Following visual examination, spots of interest were analysed by micro-XRF. It was possible to record a total of 56 measurements on the four paintings during one day while the paintings remained in the restoration workshop. Because the painting technique of each of the four paintings is very similar, ${ }^{[34]}$ analytical results of the painting 'Saint Sixtus' $(131 \mathrm{~cm} \times 54 \mathrm{~cm})$ only are presented here (Fig. 1). Table 1 shows the comprehensive semi-quantitative evaluation of the XRF spectra. Some of the findings are discussed in detail in the following.

White paint on this painting $(\mathrm{C} 08, \mathrm{C} 09)$ is characterized by strong Ca signals, while signals from $\mathrm{S}$ are absent. This indicates chalk $\left(\mathrm{CaCO}_{3}\right)$ rather than gypsum $\left(\mathrm{CaSO}_{4}\right.$ $\cdot 2 \mathrm{H}_{2} \mathrm{O}$ ). The yellow-ochre tone of the coat $(\mathrm{C} 4, \mathrm{C} 11)$ is pigmented with iron oxide yel- low, as indicated by the intense Fe peak. $\mathrm{Pb}$ $\mathrm{L}$ peaks of varying intensity indicate lead pigment; in this case most probably lead white $\left(\mathrm{Pb}_{3}\left(\mathrm{CO}_{3}\right)_{2}(\mathrm{OH})_{2}\right)$ according to the observed shades. $\mathrm{Ca}$ and $\mathrm{K} / \mathrm{Si}$ signals indicate chalk and clay minerals and therefore suggest a natural source for the pigment. There are significant small signals for elements that might initially appear unusual: $\mathrm{Ti}$ is another indicator for a natural earth pigment, because titanium minerals like ilmenite $\left(\mathrm{FeTiO}_{3}\right)$ are minor but frequent constituents of sediments derived from rocks. ${ }^{[35]}$ Similarly, Mn indicates manganese minerals (e.g. manganite $\mathrm{MnOOH}$, pyrolusite $\mathrm{MnO}_{2}$ ), which occur as the colouring component of brown earth pigments ("natural umber'). Zn was described in the literature as a typical impurity in brown earth pigments. ${ }^{[29]} \mathrm{XRF}$ analysis of the flesh tones on the face of Saint Sixtus (C06, C07 (Fig. 2b, Fig 2c, Fig. 3)) shows two elements which can be attributed to red pigments: $\mathrm{Pb}$ hints at minium $\left(\mathrm{Pb}_{3} \mathrm{O}_{4}\right)$ as well as to lead white and $\mathrm{Hg}$ hints to cinnabar, of course. These pigments are mixed with chalk as indicated by the $\mathrm{Ca}$ signals and probably with lead white as indicated by the strong $\mathrm{Pb}$ signal. 
The $\mathrm{Cu}$ signals can be attributed to a green layer of copper green, which is more visible on C07. Dark red-brown tones on the coat seam $(\mathrm{C} 10$, Fig. $2 \mathrm{~d})$ as well as on the painted frame (C12) show very similar spectra (Fig. 4) which are dominated by the strong $\mathrm{Fe}$ signal. This indicates iron oxide red $\left(\mathrm{Fe}_{2} \mathrm{O}_{3}\right)$ as the main pigment, while the other elements of medium concentration indicate chalk and a lead pigment (lead white or minium). Several trace elements hint at silicate $(\mathrm{K}, \mathrm{Si})$ and accessory minerals ( $\mathrm{Zn}, \mathrm{Mn}, \mathrm{Ti}$ ) as discussed above. This suggests that a natural earth pigment (ochre) was used as raw material to produce a red pigment by heating ('burnt ochre'). In contrary to the dark red, a clear red paint was used for the sceptre (C01, Fig. 5). The spectrum from this spot shows strong signals of $\mathrm{Hg}$ indicating cinnabar $(\mathrm{HgS})$ as the red pigment. The term 'cinnabar' is used rather than 'vermillion' because it is likely that the natural mercury sulphide was used. This expensive pigment probably was mixed with an excess of the cheaper minium, as indicated by the high $\mathrm{Pb}$ signal. Bright yellow colour on the gloves (C02) and lights on the coat $(\mathrm{C} 05, \mathrm{C} 16)$ are characterized by a low concentration of $\mathrm{Sn}$, which together with lead may indicate lead-tin yellow $\left(\mathrm{Pb}_{2}\right.$ $\mathrm{SnO}_{4}$ ). Nevertheless, the light on the coat

Table 1. Micro-XRF results for the painting 'Saint Sixtus' and interpretation. Designation of semiquantitative evaluation: $\underline{X} \underline{I}=$ main component, $\underline{\mathrm{X}}=$ high concentration, $\mathrm{X}=$ medium concentration,

$(\mathrm{X})=$ traces

\begin{tabular}{|c|c|c|}
\hline Spot no & colour / detail & XRF result \\
\hline $\mathrm{C} 01$ & $\begin{array}{l}\text { red / sceptre } \\
\text { Fig. } 2 a\end{array}$ & $\underline{\mathrm{Pb} !, \mathrm{Hg}}, \mathrm{Ca}, \mathrm{Fe},(\mathrm{Cu})$ \\
\hline C02 & $\begin{array}{l}\text { bright yellow / } \\
\text { gloves }\end{array}$ & $\frac{\mathrm{Pb} !}{\mathrm{Mn})} \mathrm{Ca}, \mathrm{Sn}, \mathrm{Cu}, \mathrm{Fe},(\mathrm{Sr}$ \\
\hline $\mathrm{CO3}$ & blue / coat & $\frac{\mathrm{Cu} ! \mathrm{Fe}, \mathrm{Ca}}{(\mathrm{K}, \mathrm{Pb}, \mathrm{Bi})}, \mathrm{Mn}$, \\
\hline C04 & ochre / coat & $\frac{\mathrm{Pb}, \mathrm{Fe}, \mathrm{Cu}, \mathrm{Ca}, \mathrm{Ti}, \mathrm{Mn}, \mathrm{Zn} \text {, }}{(\mathrm{Si}, \mathrm{K})}$ \\
\hline
\end{tabular}

yellow-white / light $\mathrm{Pb}$ !, Fe, Ti, Cu, Ca, Sn, on brocade

\section{(Si, Mn)}

flesh tone / cheek Fig. $2 b$

flesh tone, green underpaint / face Fig. 2c

grey / ornament on tiara

white / tiara

red-brown / coat seam

Fig. 2d

yellow-ochre / coat seam

red-brown / painted frame

black / underdrawing

black / contour line

black over green / possibly alteration (Mn) $\mathrm{Mn}, \mathrm{Zn}$ )

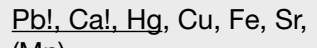

$\mathrm{Pb}$ !, $\mathrm{Cu}, \mathrm{Ca}, \mathrm{Hg}, \mathrm{Fe}, \mathrm{K}$, (Sr, Si, Mn)

$\mathrm{Ca}$ !, $\mathrm{Pb}, \mathrm{Fe}, \mathrm{Cu}, \mathrm{K},(\mathrm{Hg}, \mathrm{Sr}$,

Ca!, $\mathrm{Pb}, \mathrm{Fe}, \mathrm{Cu}, \mathrm{K},(\mathrm{Sr}, \mathrm{Mn}$, $\mathrm{Hg}, \mathrm{Zn},(\mathrm{Ti}))$

Fe!, $\mathrm{Ca}, \mathrm{Pb}, \mathrm{Cu}, \mathrm{Mn}, \mathrm{Ti}, \mathrm{K}$, (Zn, Si, Sr, (Cl))

Fe!, $\mathrm{Pb}, \mathrm{Ca}, \mathrm{Cu}, \mathrm{Mn}, \mathrm{Ti}$, $\mathrm{Zn},(\mathrm{K}, \mathrm{Si}, \mathrm{Sr},(\mathrm{Al}, \mathrm{P}))$

Fe!, $\mathrm{Ca}, \mathrm{Pb}, \mathrm{Cu}, \mathrm{Mn}, \mathrm{Ti}$, $\mathrm{Zn}, \mathrm{K},(\mathrm{Sr}, \mathrm{Cr}, \mathrm{Si})$

$\mathrm{Cu}$, $\mathrm{Ca}, \mathrm{Fe}, \mathrm{K}, \mathrm{As}, \mathrm{Pb}$, (Mn, Cl, Si)

$\mathrm{Ca}, \mathrm{Cu}, \mathrm{Fe}, \mathrm{K}, \mathrm{Pb}, \mathrm{Hg}$, (Mn, Zn, As, Sr, Ti, (Si))

Cu!, $\mathrm{Ca}, \mathrm{Fe}, \mathrm{Pb},(\mathrm{K}, \mathrm{Mn}$, $\mathrm{Hg}, \mathrm{Sr},(\mathrm{Ba}))$

white / light on coat Fe!, $\mathrm{Pb}, \mathrm{Ca}, \mathrm{Cu}, \mathrm{Sn}, \mathrm{Ti}$, seam

Fig. 2d interpretation

minium $\left(\mathrm{Pb}_{3} \mathrm{O}_{4}\right)$, lead white $\mathrm{Pb}_{3}\left(\mathrm{CO}_{3}\right)_{2}(\mathrm{OH})_{2}$ possible, cinnabar $(\mathrm{HgS})$, chalk $\left(\mathrm{CaCO}_{3}\right)$

lead white / massicot $\mathrm{PbO}$ ), less chalk, traces of lead-tin yellow $\left(\mathrm{Pb}_{2} \mathrm{SnO}_{4}\right)$

copper blue, chalk

iron oxide yellow $(\mathrm{FeOOH})$, lead white / massicot, copper blue, Ti containing accessory mineral (probably ilmenite $\mathrm{FeTiO}_{3}$ )

lead white / massicot, iron oxide yellow,

less lead-tin yellow

minium / lead white, chalk, cinnabar

minium / lead white, iron oxides, chalk, cinnabar, copper green

chalk, traces of other pigments

chalk, traces of other pigments

iron oxide red $\left(\mathrm{Fe}_{2} \mathrm{O}_{3}\right)$, chalk, lead white / minium

iron oxide yellow, lead white / massicot / minium, less chalk copper blue/-green

iron oxide red $\left(\mathrm{Fe}_{2} \mathrm{O}_{3}\right)$, chalk, lead white / minium, copper pigment (adjacent green paint)

copper green, less chalk, lead pigments, iron oxides (no indication of black pigment)

chalk, traces of other pigments (no indication of black pigment)

copper green, less chalk, iron oxide, traces of lead white (no indication of black pigment)

iron oxides, lead white / minium, less chalk and lead-tin yellow (more $\mathrm{Pb}$ than in $\mathrm{C} 10$ )
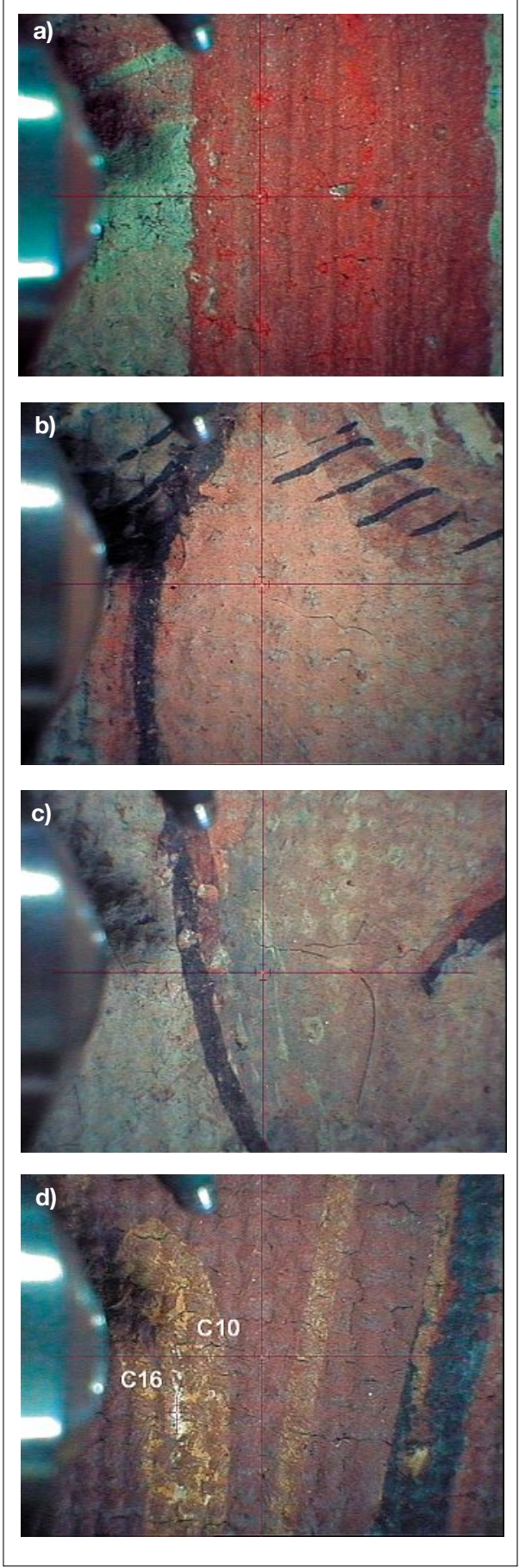

Fig. 2. a) Detail of 'Saint Sixtus' (Halberstadt), micro-XRF measuring position on the sceptre, clear red (C01); b) micro-XRF measuring position: flesh tone (C06); c) micro-XRF measuring position flesh tone with green glaze (C07); d) micro-XRF measuring positions: red-brown coat seam (C10) and bright light on coat seam (C16). For all images: video image from the measuring head, image width $=15 \mathrm{~mm}$.

seam $(\mathrm{C} 16)$ is more clearly characterized by an elevated $\mathrm{Pb}$ signal as compared to the red paint below (C10) (Fig. 4). Hence, the main component of the highlight is lead white. Blue and green paints (C3, C15) showed high concentrations of $\mathrm{Cu}$, indicating the respective blue or green copper compounds (e.g. azurite $\mathrm{Cu}_{3}\left(\mathrm{CO}_{3}\right)_{2}(\mathrm{OH})_{2}$ or malachite 


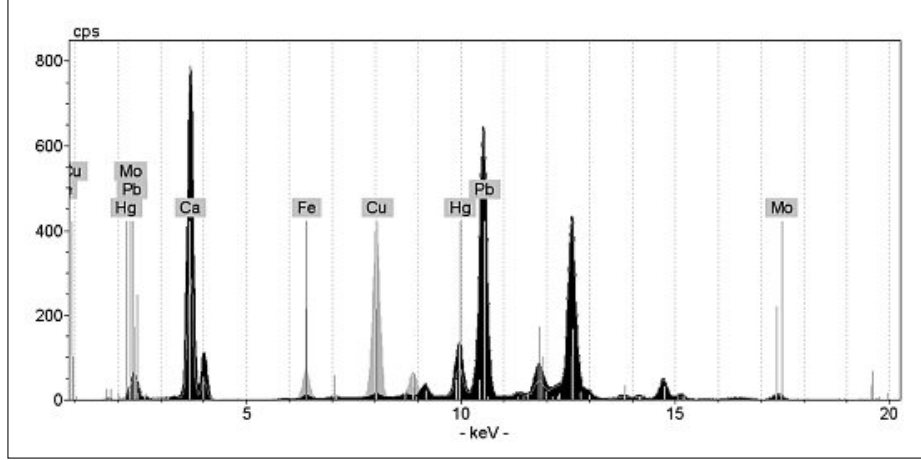

Fig. 3. Micro-XRF spectra from 'Saint Sixtus' (Halberstadt), black = flesh tone $(\mathrm{C06})$, grey $=$ flesh tone with green glaze (C07) .

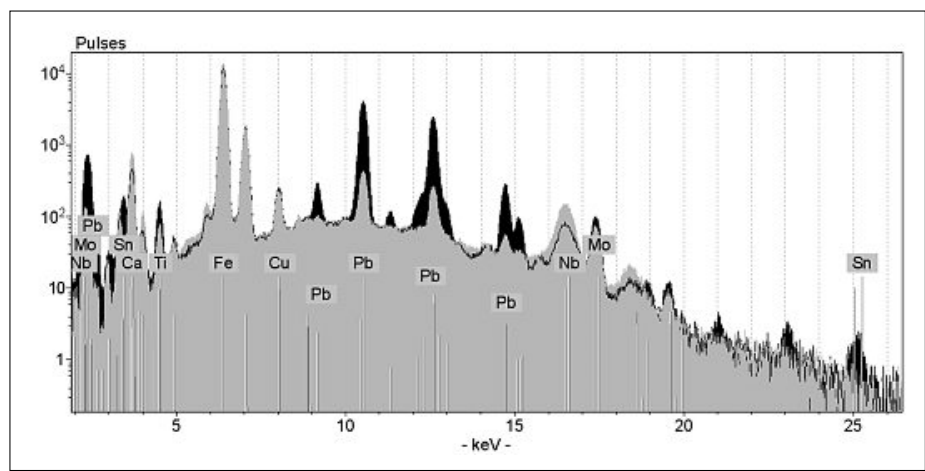

Fig. 4. Micro-XRF spectra from 'Saint Sixtus' (Halberstadt), grey = redbrown coat seam (C10), black = bright light on coat seam (C16), (note the logarithmic ordinate).

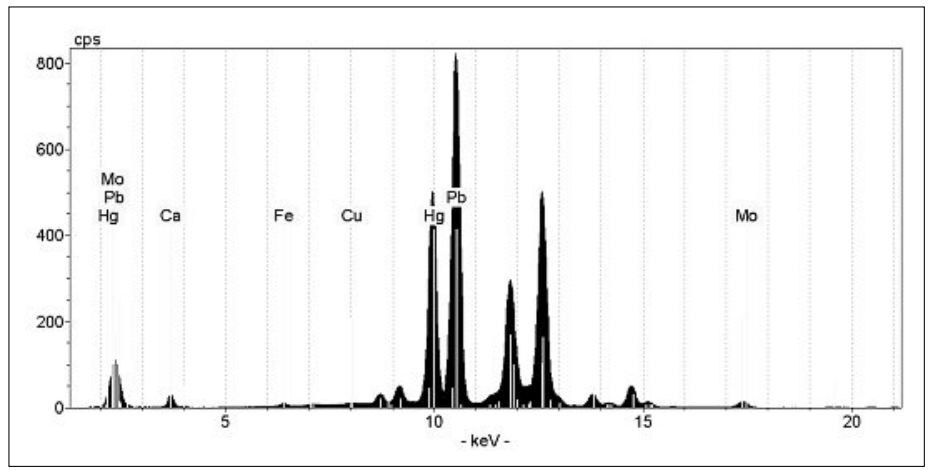

Fig. 5. Micro-XRF spectrum from 'Saint Sixtus' (Halberstadt), red paint in the sceptre (C01).

$\left.\mathrm{Cu}_{2}\left(\mathrm{CO}_{3}\right)(\mathrm{OH})_{2}\right)$. For spot $\mathrm{C} 15$ malachite could be verified by polarized light microscopy (PLM) and FT-IR spectroscopy in a sample taken from the same spot. However, other green pigments (verdigris, i.e. basic copper(II)acetate, and antlerite $\mathrm{Cu}_{3}\left(\mathrm{SO}_{4}\right)$ $\left.(\mathrm{OH})_{4}\right)$ were analyzed by PLM and FT-IR in samples taken from the painting 'Saint Stephanus' from the 'Halberstädter Heiltumsschrank'. ${ }^{[33]}$ Hence, a specific copper compound must not be assumed only from the presence of copper and has to be verified by other analytical methods which then usually require a sample. Some black lines $(\mathrm{C} 13, \mathrm{C} 14, \mathrm{C} 15)$ were analyzed, but no hints to a particular black pigment were detected.

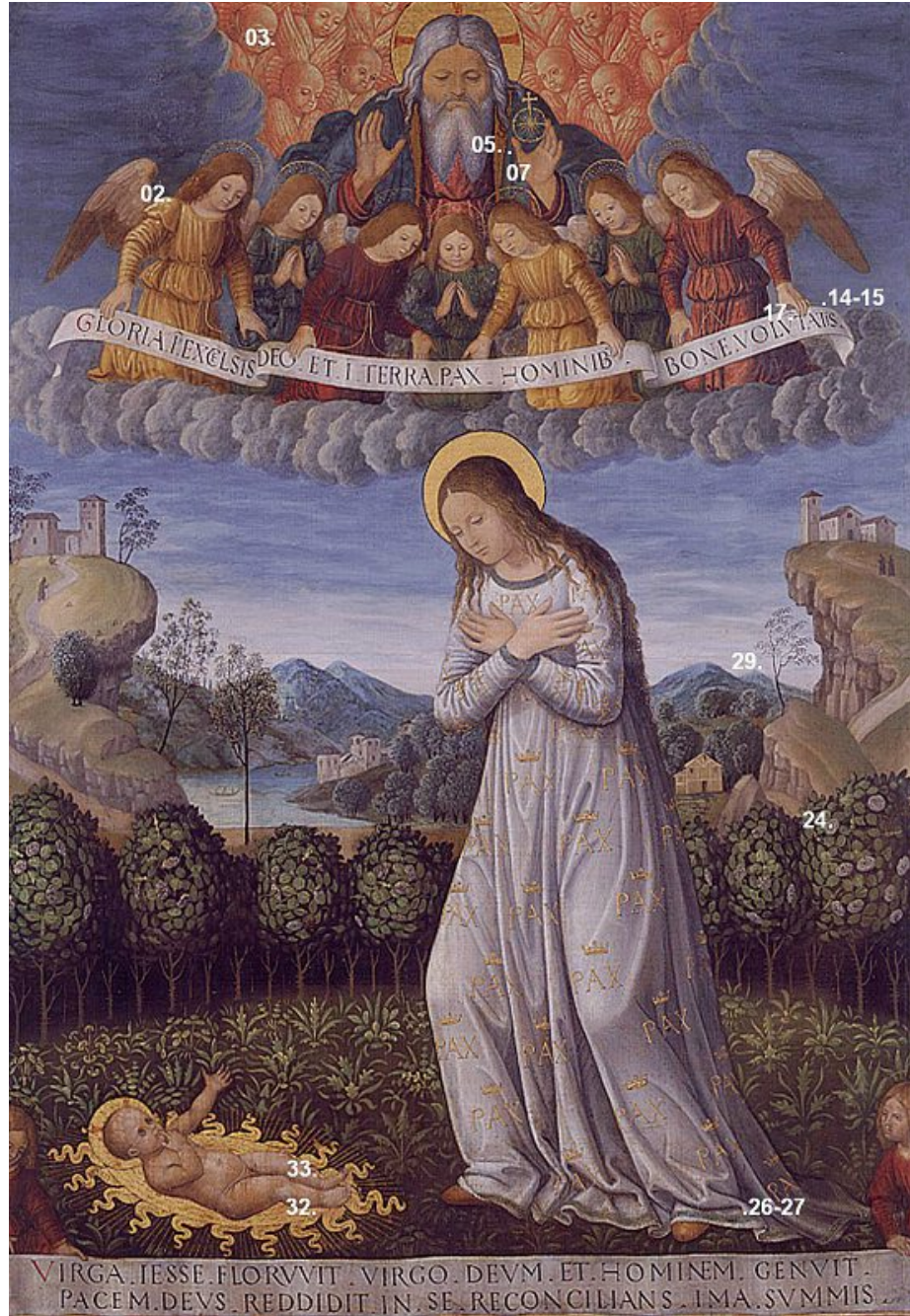

Fig. 6. Giovanni Ambrogio Bevilacqua, 'Maria, das Kind anbetend', 15001510, $152 \mathrm{~cm} \times 107 \mathrm{~cm}$, Gemäldegalerie Alte Meister Dresden. Numbers correspond to the micro-XRF measuring spots. Photograph: Staatliche Kunstsammlungen Dresden, Kluth / Estel. around $1500-1510$ and is on exhibition at the Gemäldegalerie Alte Meister at Dresden (Fig. 6). Analysis of the painting materials was requested to complement the optical examination and to provide information to those who made copies of the painting. It was decided to use micro-XRF as a strictly non-destructive method for the comprehensive survey of the pigments. Additional investigations were carried out on seven samples taken from the painting (microscopy, binding media analyses) after that, which are discussed elsewhere. ${ }^{[37]}$ Representative coloured areas were selected and documented prior to the setup of the Artax and subsequent measurements. Due to the light weight and modest size of the painting, the measurements were easily carried out using the standard tripod of the spectrometer (Fig. 7). It was possible to measure a total of 36 spots in a few hours, while the painting was in the restoration workshop. Table 2 shows the comprehensive semi-quantitative evaluation of XRF spectra of representative 


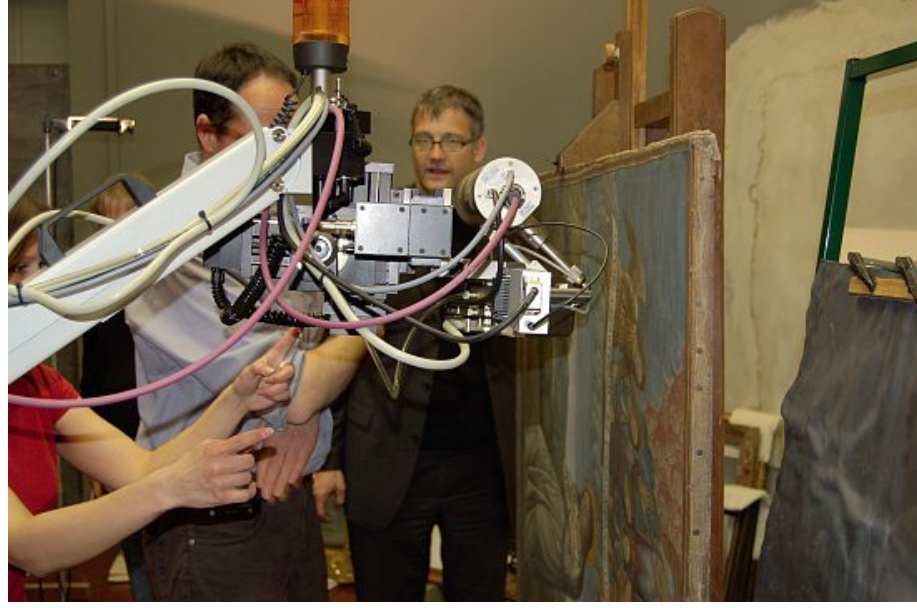

Fig. 7. Micro X-ray fluorescence setup. The Artax measuring head is in the middle with the X-ray tube above the SDD detector. Photograph: Ivo Mohrmann. tones. Some of them are discussed in detail in the following.

Generally, all white areas (e.g. Mary's robe, spot 27), as well as lighter colours (e.g. sky above the mountains, spot 29) showed pronounced peaks for $\mathrm{Pb}$ which, of course, is consistent with lead white. The spot on the sky shows a slight pink shading with cinnabar as indicated by the small $\mathrm{Hg}$ signals. Lead white was confirmed both by PLM and FT-IR in two light blue areas from the sky. Lead white was also applied in highlights, such as on the faces of the cherubim, and on an angel's robe. The black letters on the lower and upper scripture band (spot 17) did not show any difference in the XRF spectrum compared to the white ground. Therefore, carbon black can be assumed as the pigment following the discussion above. The red tone of the cherubim in the sky (spot 03) as well as the middle of the rose blossoms (spot 24) was achieved by cinnabar, as indicated by $\mathrm{Hg}$ peaks. The yellow areas in two of the
Table 2. Representative micro-XRF results for the painting 'Mary adoring the child' and interpretation. Designation of semi-quantitative evaluation: $\underline{X}=$ high concentration, $X=$ medium concentration, $(X)=$ traces

\begin{tabular}{|c|c|c|c|}
\hline Spot no & colour / detail & XRF result & interpretation \\
\hline 27 & white / Mary's robe & $\underline{\mathrm{Pb}}, \mathrm{Cu},(\mathrm{Ca}, \mathrm{Fe}, \mathrm{K}, \mathrm{Ba})$ & $\begin{array}{l}\text { lead white, copper blue (adja- } \\
\text { cent) }\end{array}$ \\
\hline 29 & $\begin{array}{l}\text { white / sky above } \\
\text { mounts }\end{array}$ & $\underline{\mathrm{Pb}}, \mathrm{Cu}, \mathrm{Hg}(\mathrm{Ca}, \mathrm{Fe}, \mathrm{Ba}, \mathrm{K})$ & $\begin{array}{l}\text { lead white, little copper blue } \\
\text { and cinnabar }\end{array}$ \\
\hline 17 & black / top writing & $\begin{array}{l}\frac{\mathrm{Pb}}{\mathrm{Cu}}, \mathrm{Fe}, \mathrm{Ca}(\mathrm{Al}, \mathrm{Si}, \mathrm{P}, \mathrm{K}, \mathrm{Ti} \\
\end{array}$ & $\begin{array}{l}\text { lead white, earth pigment (from } \\
\text { underlaying paint), (no indica- } \\
\text { tion of black pigment) }\end{array}$ \\
\hline 03 & red / Cherubim & $\underline{\mathrm{Pb}}, \underline{\mathrm{Hg}}, \mathrm{Ca}, \mathrm{Fe}, \mathrm{Cu}(\mathrm{Sn})$ & $\begin{array}{l}\text { cinnabar, minium / lead white, } \\
\text { iron oxide, lead-tin yellow }\end{array}$ \\
\hline 24 & $\begin{array}{l}\text { pink / rose blos- } \\
\text { som }\end{array}$ & $\underline{\mathrm{Pb}}, \mathrm{Cu}, \mathrm{Hg},(\mathrm{K}, \mathrm{Ca}, \mathrm{Fe})$ & lead white / minium cinnabar \\
\hline 33 & $\begin{array}{l}\text { flesh tone / Jesus' } \\
\text { leg }\end{array}$ & $\begin{array}{l}\mathrm{Pb}, \mathrm{Hg}, \mathrm{Fe}(\mathrm{K}, \mathrm{Ca}, \mathrm{Mn}, \mathrm{Cu}, \\
\mathrm{Cd}, \mathrm{Sn})\end{array}$ & $\begin{array}{l}\text { lead white / minium, cinnabar, } \\
\text { earth pigment }\end{array}$ \\
\hline 02 & $\begin{array}{l}\text { ochre / angel's } \\
\text { robe }\end{array}$ & $\begin{array}{l}\frac{\mathrm{Fe}}{\mathrm{Mn}}, \mathrm{Cu}, \mathrm{Ca}, \mathrm{Pb},(\mathrm{Si}, \mathrm{K}, \mathrm{Ti} \\
\mathrm{M},\end{array}$ & iron oxide hydroxide etc. \\
\hline 05 & $\begin{array}{l}\text { green / God the } \\
\text { father's robe }\end{array}$ & $\begin{array}{l}\frac{\mathrm{Cu}}{\mathrm{Zn}}, \mathrm{Ca}, \mathrm{Fe}, \mathrm{Pb}(\mathrm{K}, \mathrm{Ba}, \mathrm{Mn}, \\
\mathrm{Zg})\end{array}$ & $\begin{array}{l}\text { copper green, earth pigment, } \\
\text { less lead white, trace of orpi- } \\
\text { ment }\left(\mathrm{As}_{2} \mathrm{~S}_{3}\right)\end{array}$ \\
\hline 07 & $\begin{array}{l}\text { blue / God the fa- } \\
\text { ther's robe }\end{array}$ & $\frac{\mathrm{Cu}}{\mathrm{Mn}}, \mathrm{Pb}, \mathrm{Ca}, \mathrm{Fe}(\mathrm{Si}, \mathrm{K}, \mathrm{Ba}$ & $\begin{array}{l}\text { copper blue, less lead white, } \\
\text { earth pigment }\end{array}$ \\
\hline 14 & $\begin{array}{l}\text { blue / sky, dark } \\
\text { overpaint }\end{array}$ & $\frac{\mathrm{Cu}}{\mathrm{Mn}}, \underline{\mathrm{Pb}}, \mathrm{Ca}, \mathrm{Fe}(\mathrm{Si}, \mathrm{K}, \mathrm{Ba}$ & copper blue, lead white \\
\hline 15 & $\begin{array}{l}\text { blue / sky, first } \\
\text { greenish blue }\end{array}$ & $\frac{\mathrm{Cu} ; \mathrm{Pb}}{\mathrm{Mn})}, \mathrm{Fe}, \mathrm{Ca},(\mathrm{Si}, \mathrm{K}, \mathrm{Ba}$ & copper blue, lead white \\
\hline 26 & $\begin{array}{l}\text { gilding on blue / } \\
\text { Mary's robe }\end{array}$ & $\frac{\mathrm{Cu}}{\mathrm{Hg})} \mathrm{Au}, \mathrm{Pb}, \mathrm{Ca}, \mathrm{Fe}(\mathrm{K}, \mathrm{Ba}$, & $\begin{array}{l}\text { copper blue, lead white (from } \\
\text { robe), gold, little cinnabar }\end{array}$ \\
\hline 32 & $\begin{array}{l}\text { gilding on red } \\
\text { ground / halo }\end{array}$ & $\left.\frac{\mathrm{Pb}}{\mathrm{Sn}}, \frac{\mathrm{Fe}}{\mathrm{Hg}}, \mathrm{Au}\right)(\mathrm{Ca}, \mathrm{Cu}, \mathrm{Ti}$ & $\begin{array}{l}\text { minium / lead white, iron oxide, } \\
\text { gold, cinnabar, lead-tin yellow }\end{array}$ \\
\hline
\end{tabular}

angels' robes (spot 02 (Fig. 8)) as well as the ochre colour of the painted frame are pigmented with iron oxide hydroxide, as indicated by the intense Fe peak. The second major component is lead white, as indicated by $\mathrm{Pb}$ in varying concentrations according to the tone. A distinct peak for $\mathrm{Hg}$ indicates cinnabar. $\mathrm{Ca}$ and $\mathrm{K}$ suggest a natural source for the pigment, as well as small $\mathrm{Ti}$ and $\mathrm{Mn}$ signals which probably come from minor constituents of sediments as discussed above. Flesh tones, e.g. on the infant Jesus' leg (spot 33), mainly contain lead white. They are shaded with cinnabar, as indicated by the $\mathrm{Hg}$ peaks, although minium cannot be excluded. The presence of $\mathrm{Fe}$ as well as traces of $\mathrm{Ca}, \mathrm{Si}, \mathrm{Ti}$, and $\mathrm{Mn}$ again suggests that a natural earth pigment was added to the flesh tones. Measurements from five areas of green paint, e.g. a very coarse green pigment from the collar of God the Father's robe $(05)$ revealed $\mathrm{Cu}$ as the main colouring element. As discussed above, historical copper green pigments cannot be unambiguously identified solely from elemental analysis. At least copper chlorides (e.g. atacamite, $\left.\mathrm{Cu}_{2}(\mathrm{OH})_{3} \mathrm{Cl}\right)$ ) can be excluded in this painting due to the XRF data. In order to verify the green pigment a sample from an angel's robe was taken and investigated by PLM and FT-IR. Natural malachite together with some azurite was detected. ${ }^{[37]}$ Smaller XRF-peaks for $\mathrm{Ca}, \mathrm{Fe}$, and $\mathrm{Pb}$ indicate varying proportions of chalk, earth pigment, and lead white in the green paint, respectively. Additional traces of As in the majority of the spots of green paint may originate either from orpiment $\left(\mathrm{As}_{2} \mathrm{~S}_{3}\right)$ or impurities in natural malachite. Blue tones are mainly found in the robes of God the $\mathrm{Fa}$ ther (spot 07) and Mary (spot 26), as well as in the sky, the mountains, and the flowers. Generally, they are characterized by their high $\mathrm{Cu}$ signal. Azurite $\left(\mathrm{Cu}_{3}\left(\mathrm{CO}_{3}\right)_{2}(\mathrm{OH})_{2}\right)$ may be suggested as the pigment because the number of traditional blue copper pigments is much smaller than that of greens. This pigment of natural source was confirmed by PLM and FT-IR in two samples taken from the sky (see below). In each case, $\mathrm{Pb}$ signals of varying intensity from the blue paint indicate that lead white was mixed with the azurite in differing proportions according to the tone. Elemental gold was identified for the golden border of Mary's robe (spot 26) as well as for the golden halo around the infant Jesus (spot 32). Because of the thinness of the gold layer compared to the interaction depth of X-ray fluorescence the spectra from gilded areas are dominated by the elements from the ground layer rather than from the gold leaf. The red preparation layer contains minium, (lead white cannot be excluded), iron oxide, and cinnabar. The significant trace element Ti suggests that an earth pigment was used as raw material for the red pigment as discussed above. 

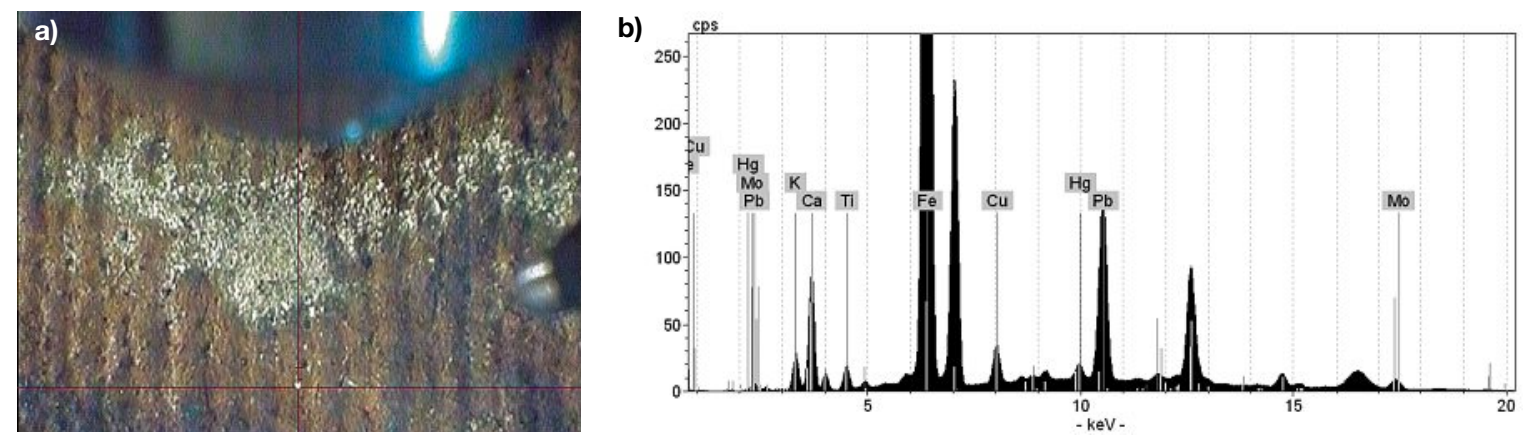

Fig. 8. a) 'Mary adoring the child', $\mu$-XRF measuring positions on a yellow angel's robe (spot 02). Video image from the measuring head, image width $=15 \mathrm{~mm}$; b) $\mu-X R F$ spectrum from a yellow angels' robe (spot 02).

It was attempted to support by micro$\mathrm{XRF}$ an observation on the painting which is related to the preservation history of the painting: Microscopic examination of the surface revealed that most parts of the sky were overpainted, presumably in a later period. Comparison of XRF measurements of closely neighbouring spots on the dark blue sky, the one with overpaint (spot 14) and the other without (spot 15) (Fig. 9) should indicate the pigment of the overpaint. Surprisingly, no significant differences were detected between both XRF spectra (Fig. 10). He-purge was applied in this case to enable detection of lighter elements (e.g. $\mathrm{Na}, \mathrm{Al}, \mathrm{Si}$ ). Typical blue pigments like $\mathrm{Na}$ - and Si-containing lapis lazuli $\left((\mathrm{Na}, \mathrm{Ca})_{8}\left[(\mathrm{Al}, \mathrm{Si}){ }_{12} \mathrm{O}_{24}\right]\right.$ $\left(\mathrm{S}_{\mathrm{SO}} \mathrm{SO}_{4}\right)$ or Co-containing smalt were to be excluded in the overpaint. Only slightly larger $\mathrm{Fe}$ peaks could indicate an iron-containing pigment. At this point strictly non-destructive analysis had to be abandoned. From two blue areas of the

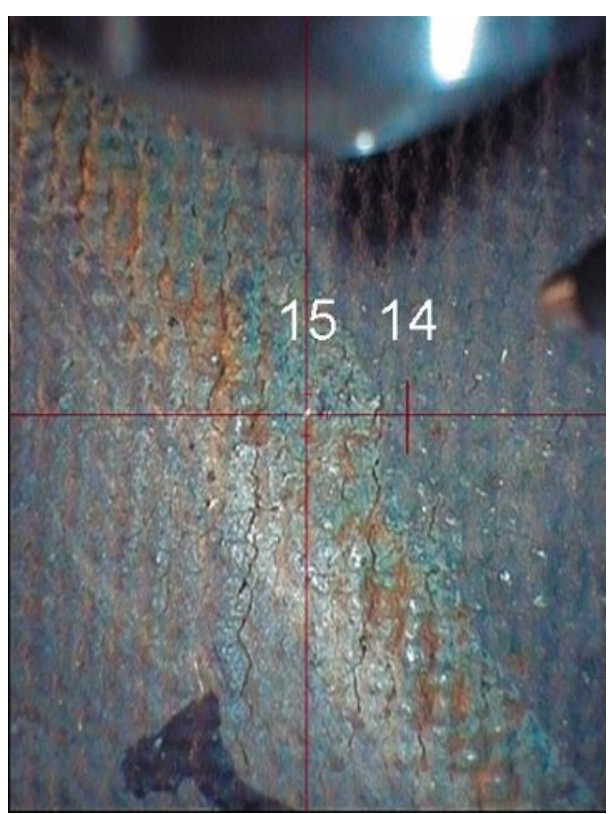

Fig. 9. 'Mary adoring the child', $\mu-X R F$ measuring positions on the sky: 14) darker blue overpaint, 15) original greenish blue. Video image from the measuring head, image width $=11 \mathrm{~mm}$

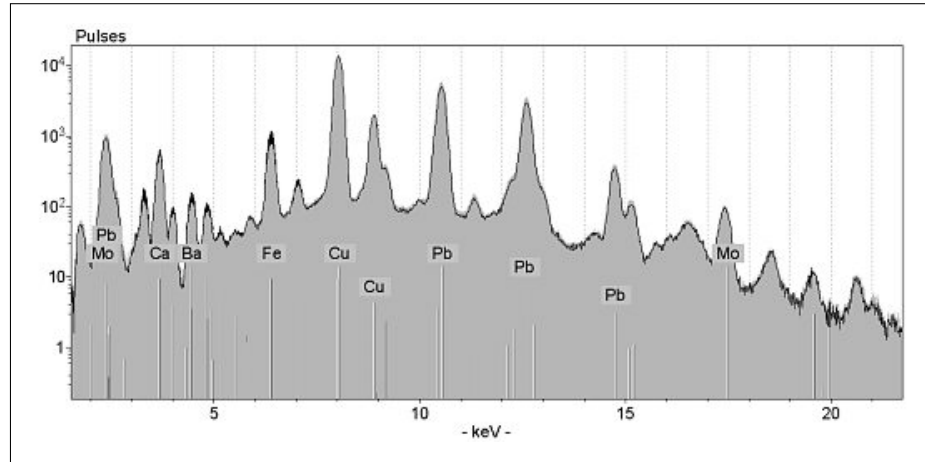

Fig. 10. 'Mary adoring the child', $\mu$-XRF spectra from the sky, grey = original greenish blue (15), black line = dark blue overpaint (14) (see Fig. 9). No significant differences (note the logarithmic ordinate).

sky (one from the lower part close to spot 29 and one from a darker blue area close to spot 15) samples were taken from the painting and cross sections were prepared for further research into the paint layer structure. ${ }^{[38]}$ Both samples exhibited a composed stratigraphy, which was investigated by incident light microscopy.[37] The first layer consists of fine lead white and coarse particles of natural azurite as described above (Fig. 11). It is covered by a thin glue-starch isolating layer. In the case of the darker surface an intense blue layer lies on top of the isolation. The very fine dark blue pigment was identified as Prussian blue $\left(\mathrm{Fe}_{4}\left[\mathrm{Fe}(\mathrm{CN})_{6}\right]_{3} \cdot \mathrm{xH}_{2} \mathrm{O}\right)$ by FT-IR. The invention date of this pigment (1704) proves the terminus post quem of the overpaint. Several further pigments were also identified in this paint layer by PLM and FTIR (lead white, iron oxide red, iron oxide hydroxide yellow, red lake, smalt, charcoal, gypsum, and silicate).

\subsection{Case Study 3}

The so-called 'Göttinger Barfüßeraltar', dated 1424 , is a double-winged triptych; the wings painted on both sides. It is the largest fully painted altarpiece in a museum world-wide ( $c$. $800 \mathrm{~cm} \times 300$ $\mathrm{cm}$ ) and is on exhibition in the Niedersächsisches Landesmuseum Hannover (Fig. 12). Within the framework of a research project the triptych has been subject to

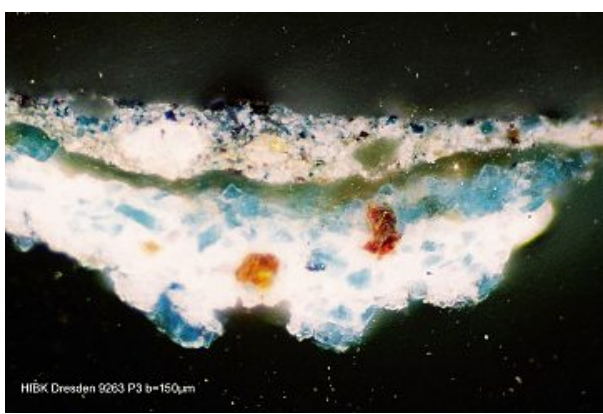

Fig. 11. 'Mary adoring the child', paint cross section of a sample from the sky under visible light. Image width $=150 \mu \mathrm{m}$.

technical research, conservation, and restoration. ${ }^{[39,40]}$ In particular the sides of the altarpiece shown on Sundays and feast-days are extensively covered by applied metal leaf and an elaborate decorating technique. The background obviously consists of pure gold. Other areas show perfectly preserved silver areas. The imitations of gold brocade textiles on the panels appear in a whole variety of golden tones. A first identification of the metal leaves was possible by optical means, which however required confirmation by non-destructive elemental analysis. Considering the date of origin the leaves could consist of pure metals, of alloys, or of 'Zwischgold', a leaf from silver and gold hammered together. Large areas of metal leaf are covered with transparent or coloured lacquers. 


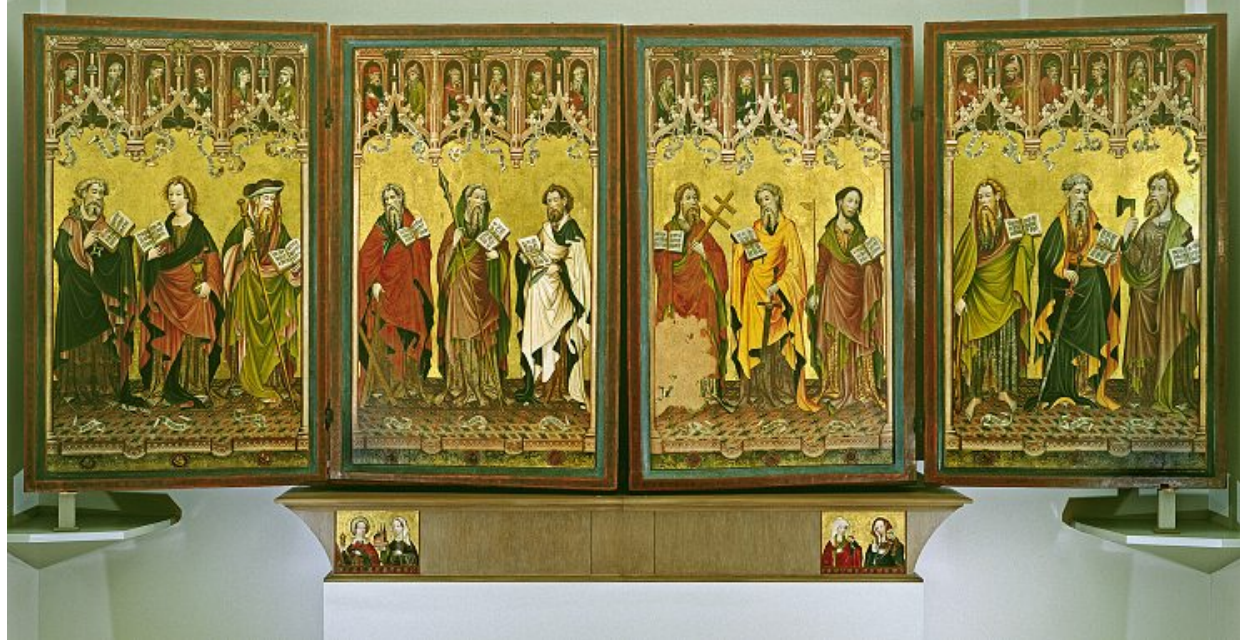

Fig. 12. 'Göttinger Barfüßeraltar' (Sunday side), 1424, ca. $800 \mathrm{~cm} \times$ ca. $300 \mathrm{~cm}$, Niedersächsisches Landesmuseum Hannover. Photograph: Stamme.

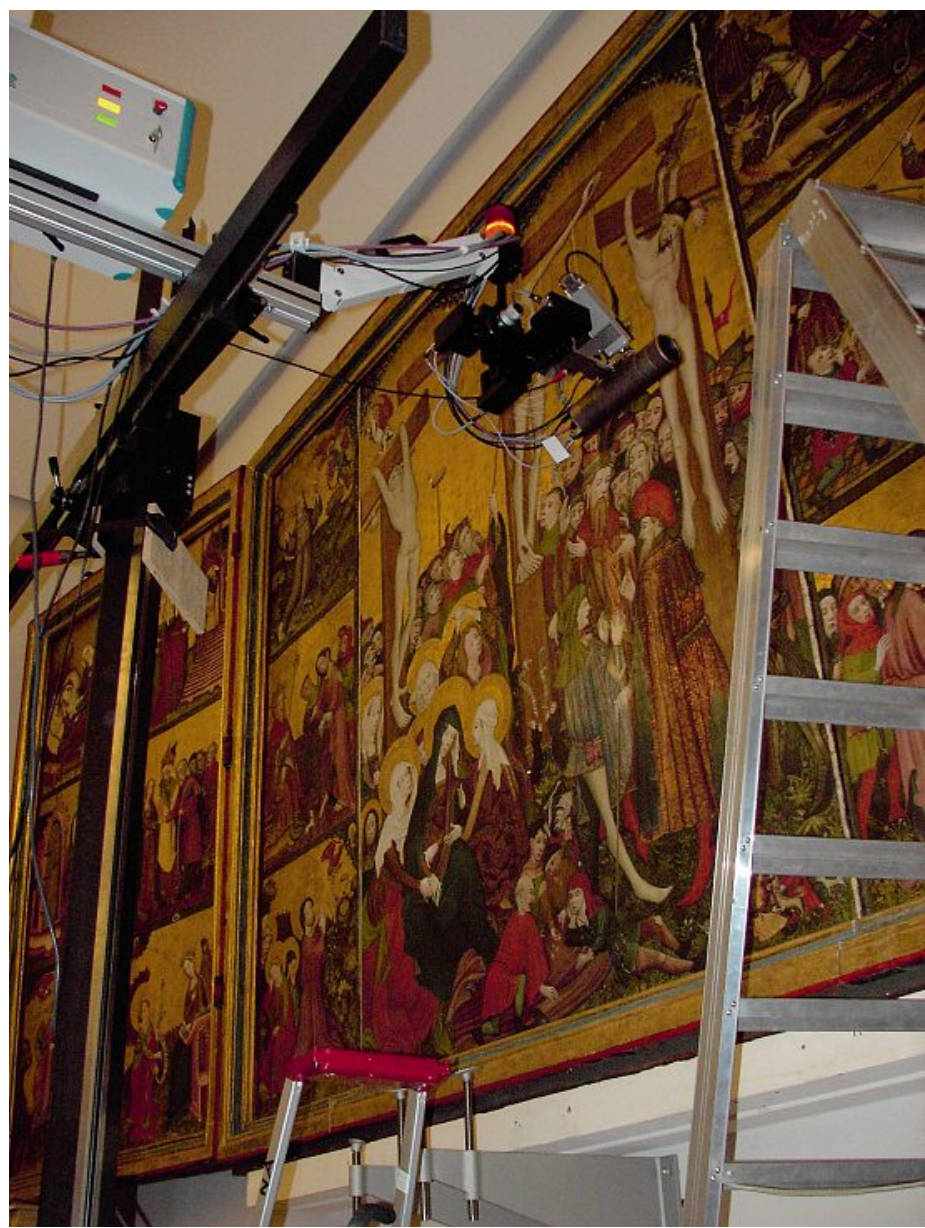

Fig. 13. Micro X-ray fluorescence measurement at the 'Göttinger Barfüßeraltar' (feast-day side). The ArtTax spectrometer is mounted on a heavy duty camera stand.

It was decided to apply micro-XRF in order to identify the metal leaves and to detect them in areas where they are covered with paint. The capacities and limitations of the ArtTAX applied to metal leaves were of special interest. Two measuring sessions were carried out in 2003 and 2004. For the specific measuring parameters see Section
3. On the basis of thorough optical investigations the measuring spots were selected and documented by the conservator before the setup of the instrument. In contrary to medium-size paintings on canvas the mounting of the spectrometer was a challenge. The enormous height of the altarpiece of about $5 \mathrm{~m}$ and the immobility of the panels made
Table 3. General layered structure of a historic painting

\begin{tabular}{|c|c|}
\hline layer & composition \\
\hline coating / varnish & $\begin{array}{l}\text { pure binder (resin, } \\
\text { protein) }\end{array}$ \\
\hline paint layer(s) & $\begin{array}{l}\text { paint }=\text { pigment } / \text { filler } \\
+ \text { binder }\end{array}$ \\
\hline $\begin{array}{l}\text { underpaint } \\
\text { or: metal leaf } \\
\text { on preparation layer }\end{array}$ & $\begin{array}{l}\text { paint } \\
\text { metal } \\
\text { filler ('bole') }\end{array}$ \\
\hline underdrawing & ink / pen \\
\hline ground & $\begin{array}{l}\text { filler (chalk / gypsum) } \\
+ \text { protein }\end{array}$ \\
\hline isolation & $\begin{array}{l}\text { pure binder } \\
\text { (protein, starch) }\end{array}$ \\
\hline support & $\begin{array}{l}\text { - textile ('canvas') } \\
\text { - wood(panel, } \\
\text { sculpture) } \\
\text { - plaster } \\
\text { - other (e.g. metal) }\end{array}$ \\
\hline
\end{tabular}

the standard tripod useless. Scaffolds could not be used either because the support for the instrument must not vibrate at any time. The solution for this problem was found in a heavy duty camera stand, which made it possible to reach spots up to about $4 \mathrm{~m}$ height. For some positions the spectrometer even had to be turned into an upsidedown position (Fig. 13). It was possible to measure a total of 32 spots in the first turn, and 33 spots in the second turn, within two days each. Additionally, reference measurements were carried out on metal sheets using both instrumental setups. Besides the non-destructive XRF analysis, analyses on samples taken from the object were carried out (discussed elsewhere ${ }^{[41]}$ ). Due to limited space only a summary of the results from the micro-XRF measurements on the 'Göttinger Barfüßeraltar' can be given here. The order follows the structure of a historic painting as given in Table 3 .

The ground layer of all panels is composed of chalk as indicated by the strong $\mathrm{Ca}$ signals in most of the spectra. Weak signals from $\mathrm{Ti}, \mathrm{Zn}$, and $\mathrm{Sr}$ may be caused by natural impurities. Furthermore, a small amount of a lead pigment can be assumed (Fig. 14). It was possible to analyze the pigment of a red first drawing over the ground layer at a paint layer defect, to which measurements could be compared. The spectrum of the red line on the ground layer shows an elevated $\mathrm{Fe}$ signal in comparison to the white ground. Hence, iron oxide pigment is a constituent of the drawing (Fig. 14). All sides of the altarpiece carry underpaint layers over the ground layer. These layers contain lead pigments (lead white and minium) ${ }^{[41]}$ as detected in paint cross sections by microscopy and elemental analysis by scanning electron microscope (SEM-EDX). This result could be confirmed by a micro-XRF 


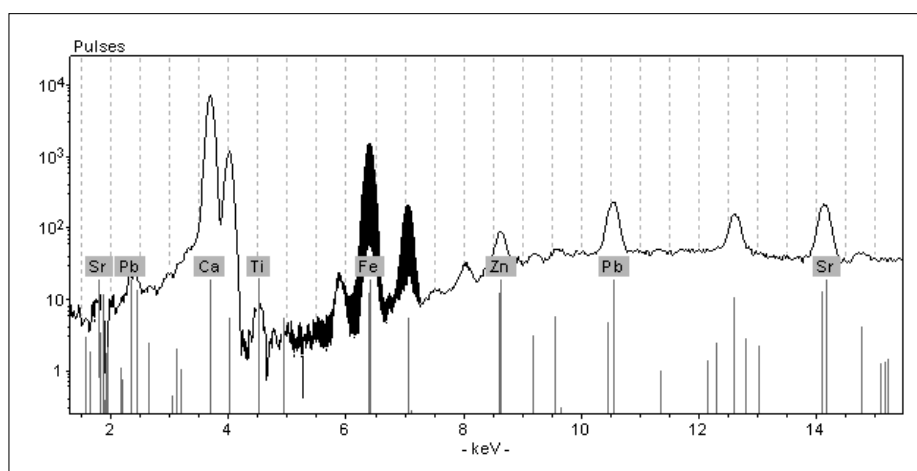

Fig. 14. $\mu$-XRF spectra from 'Barfüßeraltar' (Mo target), white = blank ground (28RF2), black = ground with red line (28RF1), (note the logarithmic ordinate).

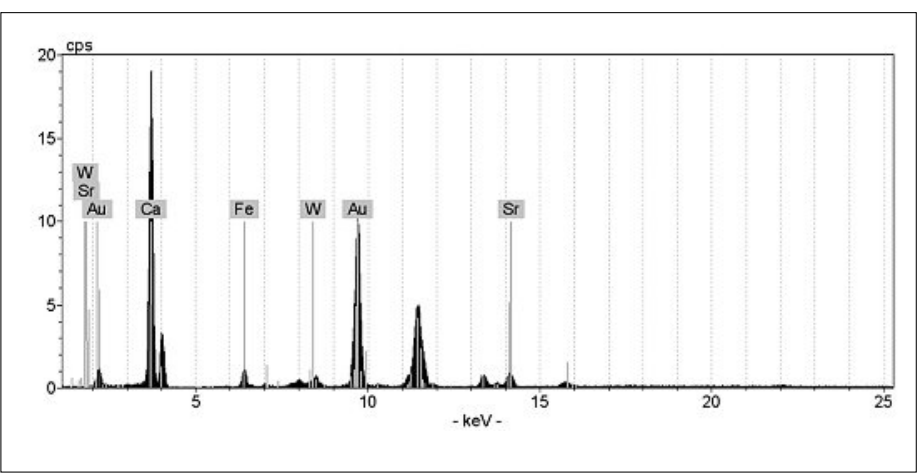

Fig. 16. $\mu$-XRF spectrum (W-target) from ‘Barfüßeraltar', golden background on the feast-day side (10RF5)
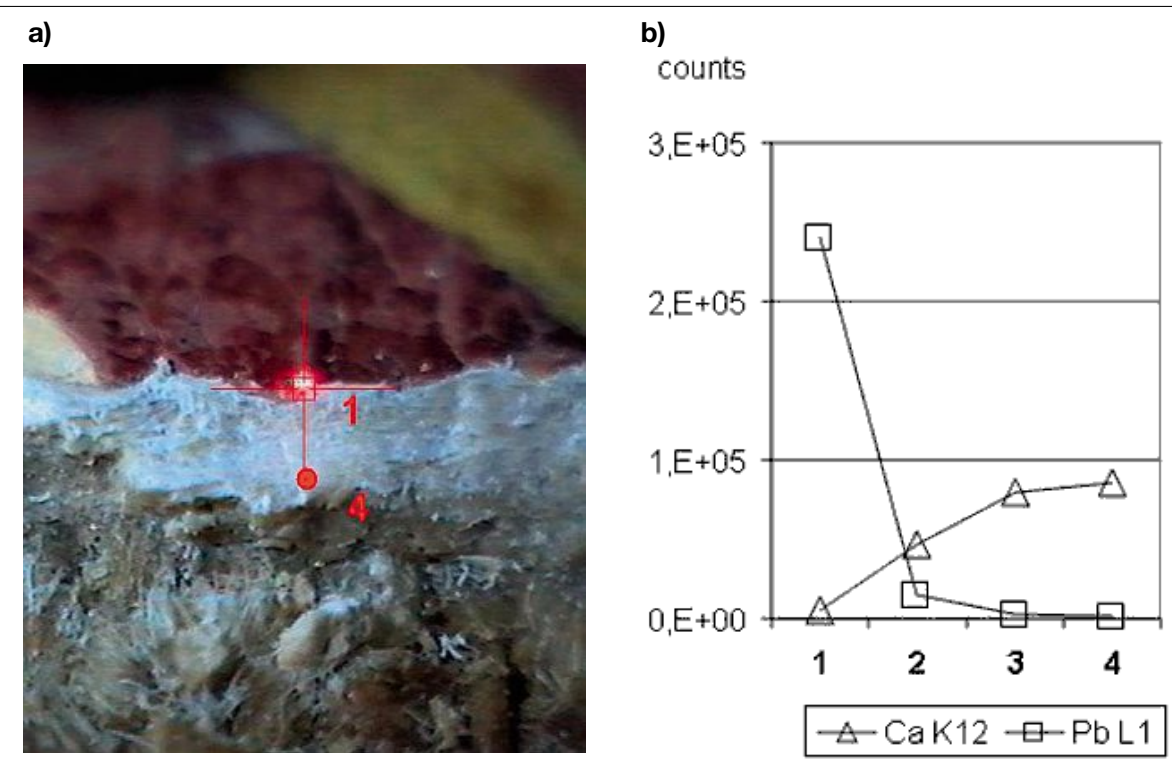

Fig. 15. a) Detail from 'Barfüßeraltar', position of the micro-XRF scan (7.5RF3) from the red paint (top, 1) down to the ground layer (middle, 4). Video image from the measuring head, length of the scan: $0.59 \mathrm{~mm}$ image width = c $4.7 \mathrm{~mm}$; b) result of micro-XRF-scan (7.5RF3) from the paint layer down to the ground layer, peak intensities of $\mathrm{Ca}$ and $\mathrm{Pb}$. Length of the scan: $0.59 \mathrm{~mm}$

scan at a fracture in the paint, where the layers from the surface down to the support were accessible: The high $\mathrm{Pb}$ signals at the surface (spot 1) drops towards the ground (spots 2-4), whereas the Ca signals from the ground increase with depth (Fig. 15).

Compared to the X-ray fluorescence depth of several micrometers up to millimetres, the thickness of the medieval metal sheets of around $1 \mu \mathrm{m}^{[42]}$ is only a fraction of this. Hence, the spectra from metal sheets were dominated by signals from the ground layer ( $\mathrm{Ca}$ and $\mathrm{Sr}$ from chalk) and from the bole ( $\mathrm{Fe}$ from iron oxide and $\mathrm{Ti}$ from accessory minerals). Nevertheless, the nature of the metal sheets on the altarpiece could be elucidated by micro-XRF. The golden background on the Sunday- and feast-day-sides was proved to be pure gold leaf (Fig. 16). Here, a quantitative evaluation of the $\mathrm{Au} / \mathrm{Ag} / \mathrm{Cu}$ ratio based on peak intensities could be attempted, because no coating layers with additional pigments were observed. The data gained with the collimator was suitable, because no polycapillary lens had suppressed the Ag-Klines. The result from the blank gold leaf on the 'Barfüßeraltar' was compared to gilt surfaces of other works from the same time ('Lüneburger Goldene Tafel', around $1418 / 20$ and 'Reliquary bust' from Uslar, around 1420 (Fig. 17), both Niedersächsisches Landesmuseum Hannover), as well as to modern gold leaf references. The gold alloys from the 'Barfüßeraltar' as well as from both other medieval works are very pure with respect to the $\mathrm{Ag}$ concentration (Fig. 18). The Au concentration lies in the range of 'Rotgold' (95.8\% mass $\mathrm{Au}=23$ karat) to 'Rosenobelgold' (97.9\% mass Au $=23.5$ karat). A further quantitative analysis of the metal sheets with respect to trace elements appeared not to be reasonable because of the ground layers and glazes that had been applied throughout the surface. Some golden areas on the Sunday- and feast-day sides such as garments, parts of the brocade, and details revealed significant

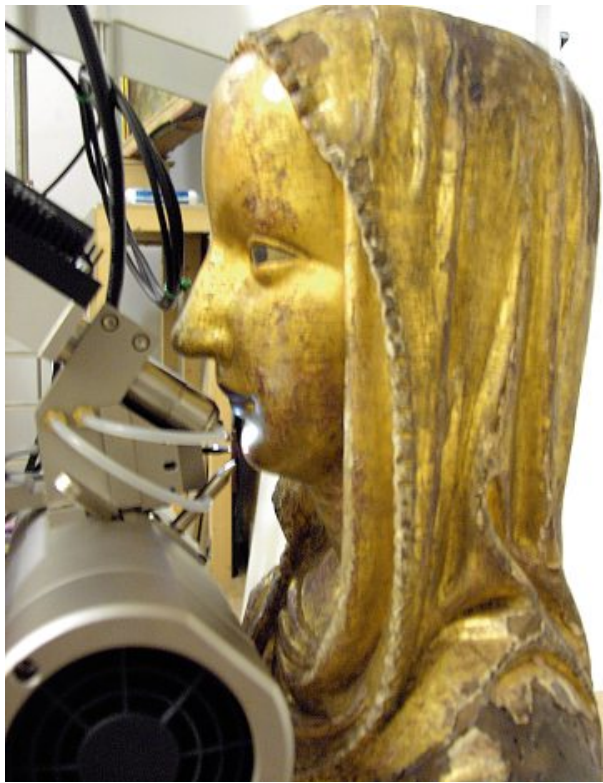

Fig. 17. Micro-XRF measurement on a sculpture: 'Reliquary bust' from Uslar, ca. 1420, Niedersächsisches Landesmuseum Hannover.

Ag peaks in the spectra (Fig. 19) and thus can be interpreted as Zwischgold. A quantitative evaluation of the Au- and Ag-signals similar to that for the gold leaves showed that the medieval Zwischgold leaves ('Barfüßeraltar' and 'Goldene Tafel') contain a relatively higher concentration of $\mathrm{Au}$ than the modern reference samples (Fig. 20). The soldiers' armour in the middle panel and some other details are made from silver leaf (Fig. 21a and b). It is divided in areas of different shade. However, they do not show any difference in the micro-XRF analysis (Fig. 21c) and thus the discolouration can be caused only by a different oxidation state of Ag or some organic colorant. Another more reddish area on that armour is obviously coloured by an iron oxide pigment, as indicated by the elevated Fe signal at that spot (18.6RF3) (Fig. 21c).

The imitations of luxurious gold brocade textiles are created in an elaborate manner: First a metal leaf was applied, which in most areas is silver in addition to 


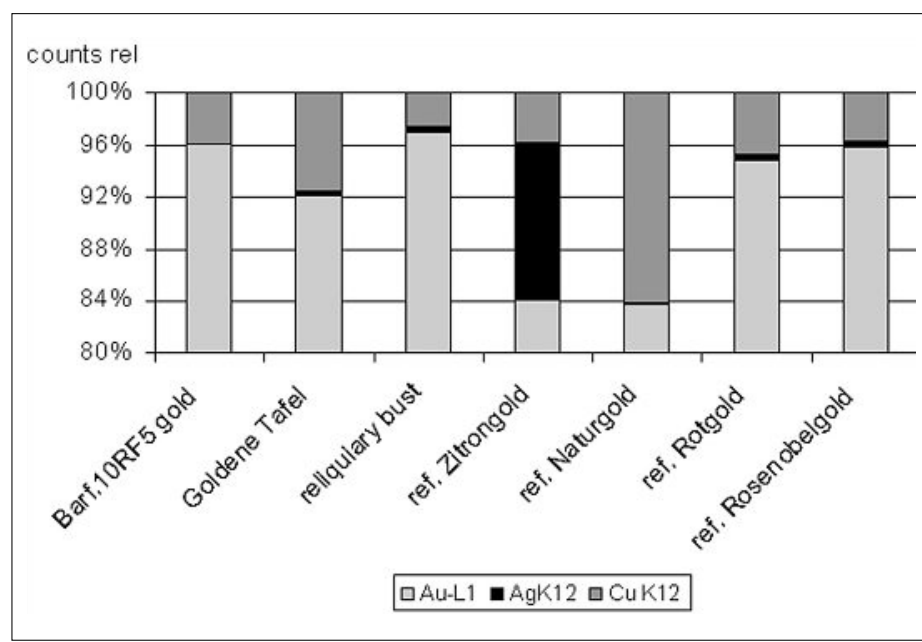

Fig. 18. Micro-XRF data (W-target) of gold leaves (ref. = modern reference samples). Calculated ratio of line intensities, normalized.

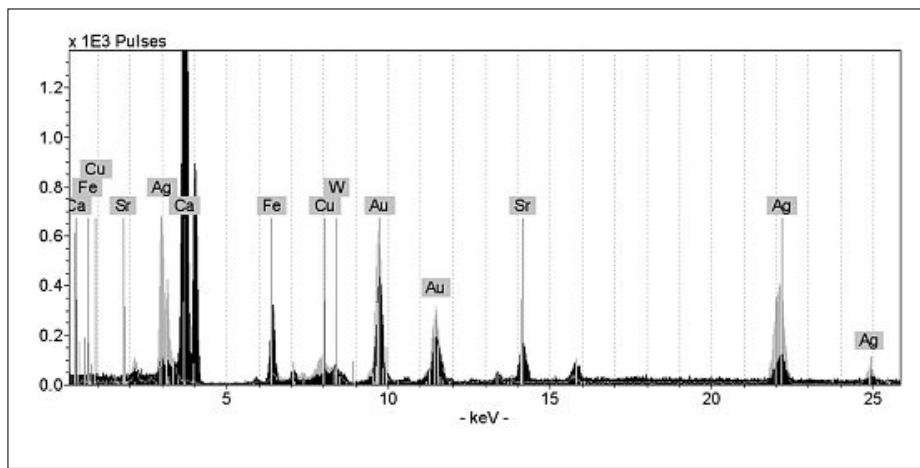

Fig. 19. Micro-XRF spectra (W-target), grey = golden leaf on feast-day side of 'Barfüßeraltar' (door, 10RF4), black: modern Zwischgold reference (gold upside).

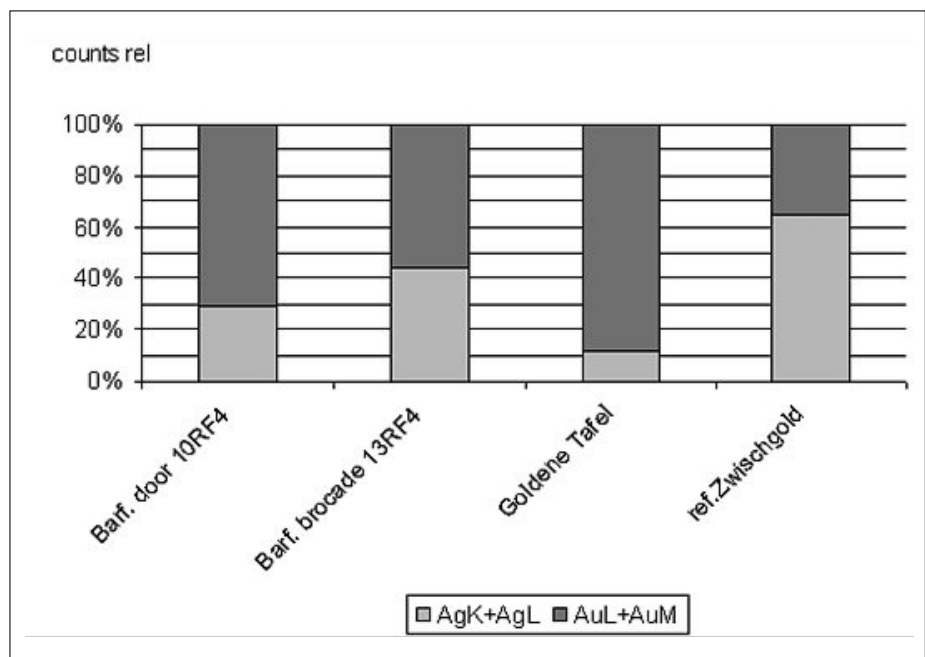

Fig. 20. Micro-XRF data (W-target) of Zwischgold leaves (ref. = modern reference sample). Calculated ratio of line intensities, normalized. the above-mentioned Zwischgold. On top mostly coloured coating. Then an ornament was painted with different opaque colours. Finally, the shadows of the pleats are indicated with a different, more transparent colour. The coating on the metal ground of of the metal foil follows a transparent and

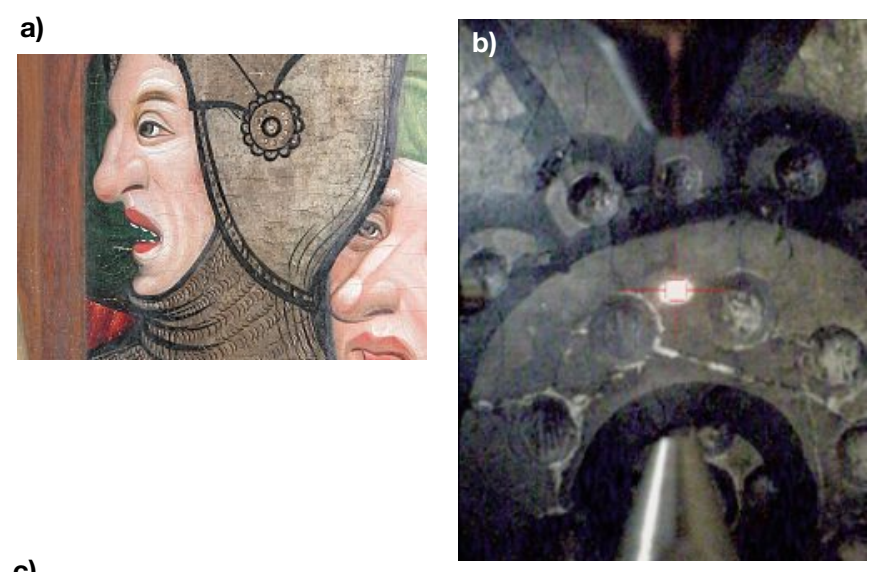

c)

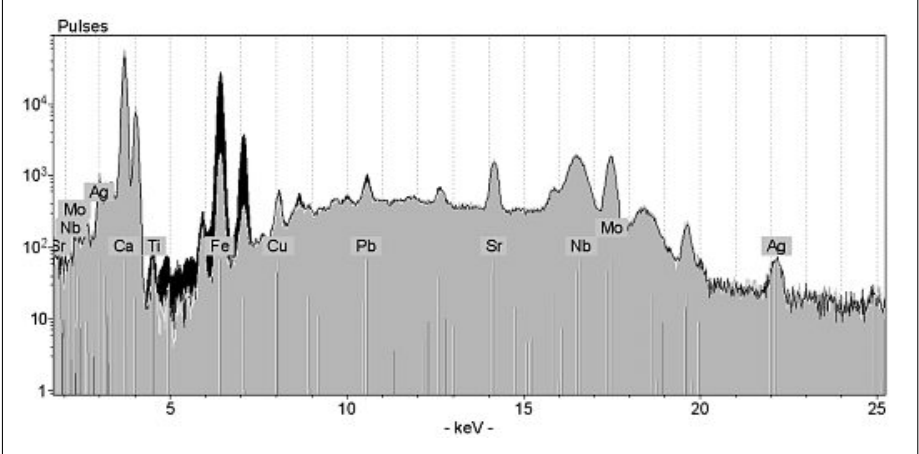

Fig. 21. a) Detail of 'Barfüßeraltar', silver armour on the middle panel, areas of different shade; b) Detail of 'Barfüßeraltar', micro-XRF measuring position: dark silver on armour (18.6RF1). Video image from the measuring head, image width $=c a .3 \mathrm{~cm}$; c) $\mu$-XRF spectra from 'Barfüßeraltar', silver armour on the middle panel, black $=$ reddish area $(18.6 \mathrm{RF} 3)$, grey $=$ dark silver (18.6RF1), white line = light silver (18.6RF2), (note the logarithmic ordinate). probably appeared in a much clearer green tone. Other silver areas in the brocade are coated with a red pigment that probably is of organic nature because it does not show any distinctive X-ray signals. For the painted decoration on the brocade micro-XRF revealed clear results: According to the spectra the blue lines contain copper-pigment (presumably azurite) and red lines contain minium und a little cinnabar, as indicated by $\mathrm{Pb}$ and $\mathrm{Hg}$, respectively. A blue-black ornament (Fig. 23a) was analyzed as cinnabar $(\mathrm{HgS})$ pigment which turned black (Fig. 23b). The painted pleats in red (Fig. 23a) contain minium as the $\mathrm{Pb}$ signal in the XRF spectra indicates. In contrast, blue painted pleats did not show any distinctive X-ray signals and hence only contain organic pigments.

On the 'Barfüßeraltar', a few fragments of narrow metal ribbons remained, which divided the small scenes on the feast-day side. As expected, the relatively bulky and homogeneous metal parts could be easily analyzed by micro-XRF (Fig. 24).[39,41] The metal ribbon consists of almost pure $\mathrm{Cu}$ with traces of $\mathrm{Fe}, \mathrm{Ni}, \mathrm{Pb}, \mathrm{As}, \mathrm{Ag}$, Sb. Three nails which fixed the metal ribbon could be characterized as a $\mathrm{Cu}$-rich, malleable brass with minor components of $\mathrm{Zn}$ and traces 


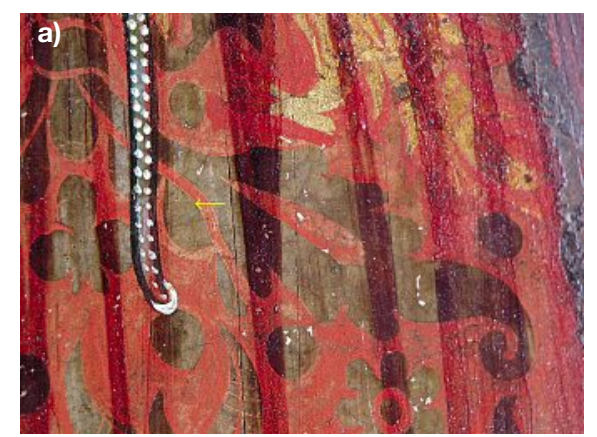

b)

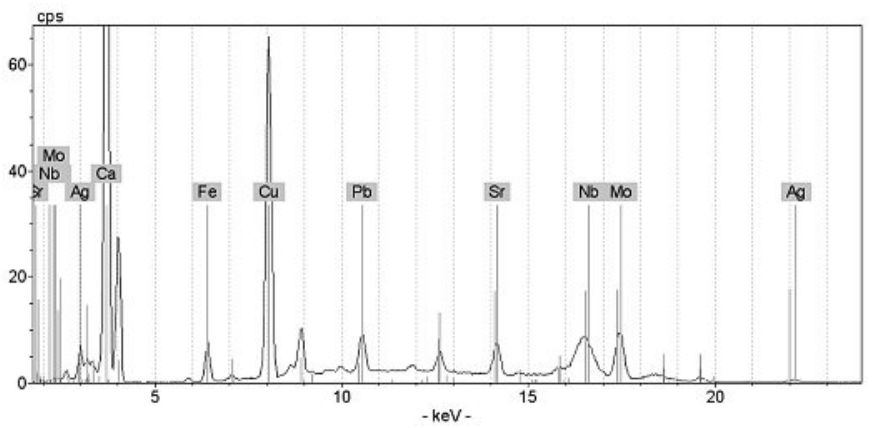

Fig. 22. a) Detail from 'Barfüßeraltar', brocade with greenish-brown glaze on silver leaf and red painted ornament. Arrow indicates micro-XRF spot (22RF3); b) microXRF spectrum (Motarget) brocade with greenish-brown glaze on silver leaf (22RF3).

Fig. 23. a) Detail of 'Barfüßeraltar', micro-XRF measuring position: black ornament (7.5RF3). Video image from the measuring head, image width $=c a$. $3 \mathrm{~cm}$; b) micro-XRF spectrum (W-target) from brocade with blue-black ornament on silver leaf (7.5RF3).

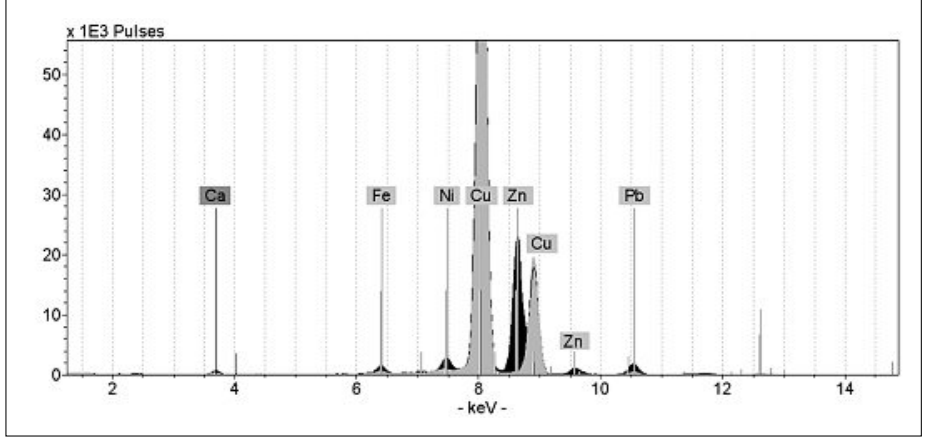

Fig. 24. Micro-XRF spectra (W-target) from 'Barfüßeraltar', black = brass nail (18.1RF2), grey = copper ribbon (18.1RF1).

of $\mathrm{Fe}, \mathrm{Ni}, \mathrm{As}$, and $\mathrm{Pb}$. Calibration of the peak intensities with quantitative chemical analysis made by AAS earlier[43] allowed the concentrations to be quantified as $\mathrm{Cu}$ $=83-90 \%$ mass and $\mathrm{Zn}=10-17 \%$ mass. $\mathrm{A}$ fragment of gilding was identified as pure gold leaf.

\section{Experimental and Technical Aspects}

\subsection{Measuring Conditions}

The measurements presented in this paper were carried out with an ArtTax/Artax system. Generation of excitation radiation as well as detection of X-ray fluorescence are combined in a compact measuring head: a small air-cooled 'mini-focus' $\mathrm{X}$-ray tube and a high resolution energy-dispersive, Peltier-cooled silicon-drift detector (SDD).
The excitation area may either be restricted by a $650 \mu \mathrm{m}$ collimator or by a polycapillary X-ray lens producing a spot of $c a$. 80 $\mu \mathrm{m}$ diameter with high intensity. ${ }^{[44]}$ Because total reflection in the polycapillary lens

Table 4. Parameters for micro-XRF measurements

$\begin{array}{llll} & \begin{array}{l}\text { case study } 1 \\ \text { and case study } 2\end{array} & \text { case study } 3 \text { (2003) } & \text { case study } 3 \text { (2004) } \\ \text { tube } & \text { Mo }(30 \mathrm{~W}) & \text { Mo }(30 \mathrm{~W}) & \mathrm{W}(30 \mathrm{~W}) \\ \text { voltage } & 45 \mathrm{kV} & 50 \mathrm{kV} & 50 \mathrm{kV} \\ \text { tube current } & 600 \mu \mathrm{A} & 600 \mu \mathrm{A} & 800 \mu \mathrm{A} \\ \text { filter } & \text { Mo }(25 \mu \mathrm{m}) & \text { Mo }(10 \mu \mathrm{m}) & \mathrm{Ni}(10 / 30 \mu \mathrm{m}) \\ \text { focus } & \text { polycapillary } & \text { polycapillary } & \text { collimator } \\ & \text { ca. } 80 \mu \mathrm{m} & \text { ca. } 80 \mu \mathrm{m} & 650 \mu \mathrm{m} \\ \text { measuring time } & 100 \mathrm{~s} & 100 \mathrm{~s} & 100 \mathrm{~s} \\ \text { He-purge } & \text { partly } & \text { partly } & \text { None }\end{array}$

disappears at energies $>20 \mathrm{keV}$ the fluorescence intensity drops dramatically at higher energies. The detailed experimental setups and parameters used for the measurements are compiled in Table 4. The fluorescence depth generally depends on the excitation energy, the line energy of the fluorescence radiation, and the matrix, i.e. the composition of the material under analysis. For the Artax the range of measuring depth was determined from a few micrometers (for $\mathrm{Na}$ ) up to some millimetres (for $\mathrm{Sb}$ ). ${ }^{[22]}$

In the measuring head a CCD camera together with a white LED illumination are integrated. This provides a magnified live image of the region under investigation, which can be saved digitally. A red laser diode is used to position the beam on the area of interest as well as to adjust the operating distance (Fig. 21b). The distance of the tube window and the detector to the surface is 
about $3 \mathrm{~mm}$. If care is taken, measurements can also be performed on convex parts of three-dimensional objects (Fig. 17). The measuring head is fixed to a motor-driven $\mathrm{x} / \mathrm{y} / \mathrm{z}$ positioning stage which can be controlled from the computer. The latest generation of Artax is equipped with a sensor that prevents contact of the measuring head with the surface. It is possible to perform a 'line scan' of subsequent XRF measurements, reasonably in the dimensions of a few millimetres. Normally, the whole instrument (apart from the laptop control) is mounted on a vibration-damped tripod which allows free positioning of the complete measuring system relative to the object under investigation (Fig. 6). In certain cases, where the dimensions of the tripod are not sufficient, the instrument may be fixed to a suitable support, such as a heavy-duty photographic stand (Fig. 13). ${ }^{[39]}$ Concerning safety regulations a distance to the source of one meter is sufficient, which must be indicated by temporary barriers. ${ }^{[22]}$

\subsection{Data Interpretation}

Evaluation of the data was performed using the programme 'ArtTAXControl' (V4.5.4.0). Depending on the excitation energy the XRF spectra show additional signals not originating from the measured object due to systematic interactions, e.g. Raleigh scattering and Compton scattering of the excitation lines as well as 'pile-up' and 'escape' effects in the detector. The interpretation of the spectra was also affected by line coincidences as given in Table 5 . Fig. 25 shows how the spectrum is influenced by the set-up: Using the polycapillary lens together with the Mo-target results in a strong suppression of the Ag-lines and a more distinct scattered excitation radiation. Here, Ag can be detected only at energy $<20$ $\mathrm{keV}$ by its weaker Ag-L-lines (AgL $\alpha 12.98$ $\mathrm{keV})$. Therefore it proved advantageous to use a collimator instead of the lens to gain the stronger Ag-K-lines (Ag-K $\alpha 122.16$ $\mathrm{keV}$ ). In both setups Au is easily detected in an intermediate energy range (Au-L-series: $8.49-13.38 \mathrm{keV}$ ).

Generally, the experimental XRF data is evaluated only in a 'semi-quantitative' way, because the intensity of the individual signals is influenced by many factors. Knowing the theoretical composition of the pigments, one tries to correlate the elements to certain compounds known as pigments. Sometimes, the colour of the paint may support interpretation. For example, presence of $\mathrm{Hg}$ in a reddish paint normally proves the presence of cinnabar (HgS) (Fig. 5).

However, interpretation of the elemental data from paintings is often ambiguous because all elements contribute that are present in the entity of the inorganic pigments, fillers and accessory substances in a paint layer, which itself may consist of

Table 5. Characteristic signals in the spectra depending on the $\mathrm{X}$-ray target, in keV

\begin{tabular}{|c|c|c|}
\hline & Mo-target & W-target \\
\hline $\begin{array}{l}\text { characteristic excitation } \\
\text { energy } \\
\text { (Raleigh scattering) }\end{array}$ & Mo-K (17.4 / $19.6 \mathrm{keV})$ & W-L (8.39 / 9.67) \\
\hline \multirow{3}{*}{$\begin{array}{l}\text { Compton scattering } \\
\text { coincidences }\end{array}$} & Nb-K (16.62 / 18.63) & not visible \\
\hline & $\begin{array}{l}\text { Mo-L-series (2.014-2.831) / } \\
\text { Au-M-series (1.981-2.883) }\end{array}$ & $\begin{array}{l}\text { W-L } \alpha 1 \text { (8.398) / Cu-K } \alpha 1 \text { (8.046); } \\
\text { W-L } \beta 1 \text { (9.672) / Au-L } \alpha 1 \text { (9.713) }\end{array}$ \\
\hline & $\begin{array}{l}\text { As } \mathrm{K} \alpha 1(10.543) / \mathrm{Pb}-\mathrm{L} \alpha 1 \\
(10.551)\end{array}$ & \\
\hline
\end{tabular}

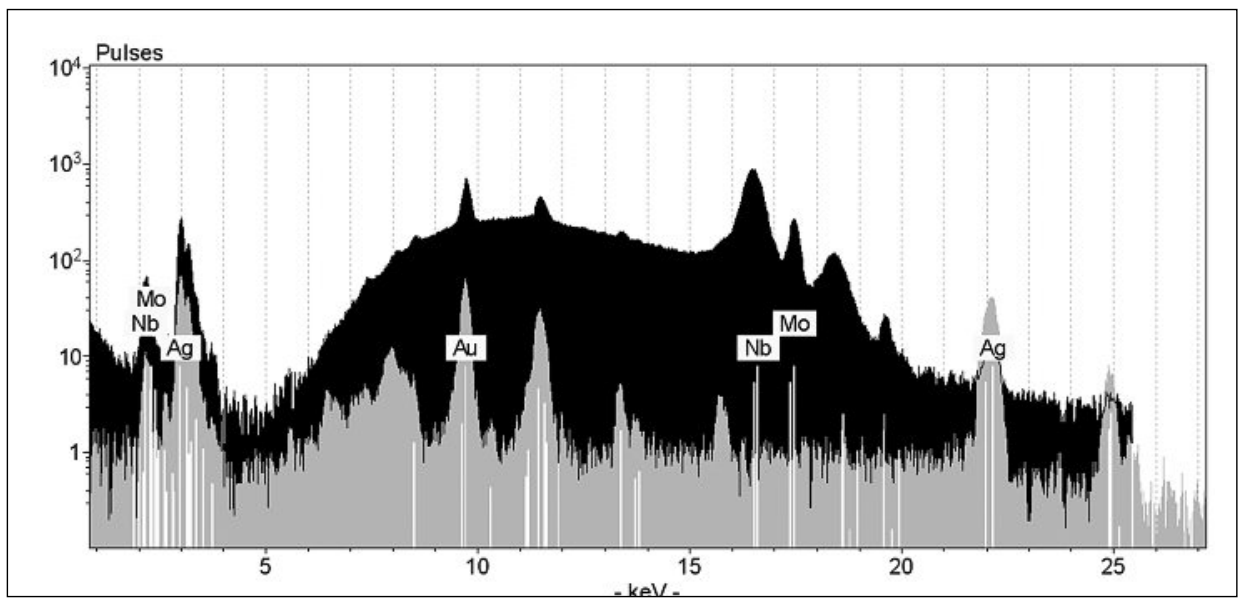

Fig. 25. Micro-XRF spectra on reference samples of metal leaves (Zwischgold): black = Mo-target, polycapillary lens, grey $=\mathrm{W}$-target, collimator.

several layers. This problem appears especially in the case of $\mathrm{Pb}$, because this element is a constituent of numerous pigments. For example, if a red paint shows lead signals, the pigments minium $\left(\mathrm{Pb}_{3} \mathrm{O}_{4}\right.$, red), massicot ( $\mathrm{PbO}$, yellow) and lead white $\left(\mathrm{Pb}_{3}\left(\mathrm{CO}_{3}\right)_{2}(\mathrm{OH})_{2}\right.$, white $)$ may be present (Fig. 3). A similar case involves the green $\mathrm{Cu}$-containing pigments, because a great number of different copper compounds are known as pigments or their degradation compounds, respectively. ${ }^{[45]}$

Data from metal leaves were also evaluated quantitatively: The intensity ratios $\mathrm{I}(\mathrm{Au}-\mathrm{L} \alpha 1): \mathrm{I}(\mathrm{Ag}-\mathrm{K} \alpha 1): \mathrm{I}(\mathrm{Cu}-\mathrm{K} \alpha 1)$ and $\quad[\mathrm{I}(\mathrm{Au}-\mathrm{L} \alpha 1)+\mathrm{I}(\mathrm{Au}-\mathrm{M} \alpha 1 / 2)]:[\mathrm{I}(\mathrm{Ag}-$ $\mathrm{K} \alpha 1)+\mathrm{Ag}-\mathrm{L} \alpha 1)]$ were calculated without calibration (Fig. 18, 20).

\section{Conclusions}

From the micro-XRF measurements on medieval paintings using the ArtTax/Artax spectrometer the following conclusions can be drawn:

- The CCD-camera together with the laser-pointer and the remote motorized positioning of the measuring head enables the measuring spot to be localized in an exact and simple fashion.

- The diameter of the measuring area (80 $\mu \mathrm{m}$ or $650 \mu \mathrm{m})$ matches the requirements of a detailed surface analysis of paintings.
- The shape of the measuring head and the measuring distance of $3 \mathrm{~mm}$ to the surface makes it difficult to analyse materials on curved surfaces of carved polychrome sculptures or on paintings close to frames.

- The option of line scan measurements performed over a damage in the paint layer made it possible to distinguish between different paint or metal layers.

- Elemental analysis on paintings on canvas with a single paint layer ('Tüchlein') revealed reliable information about pigments. Taking the range of possible mediaeval pigments into account, pigments often can be identified. However, if there are several compounds of similar elemental composition, neglecting $\mathrm{C}, \mathrm{N}$, and $\mathrm{O}$, single phases cannot be defined (e.g. copper blue and green pigments, lead pigments).

- It was possible to distinguish metal leaves ( $\mathrm{Au}, \mathrm{Ag}$, and 'Zwischgold'). However, it was not possible to determine their quality. Bulk metal fragments could be analyzed straightforwardly. The Mo-target combined with the polycapillary lens turned out to be unreliable for analysing $\mathrm{Ag}$ leaf. A collimator is favourable for the investigation of heavier elements. On the other hand, the $\mathrm{W}$-target makes it difficult to detect low contents of $\mathrm{Cu}$ and $\mathrm{Au}$ due to line coincidences.

- The interpretation of XRF spectra resulting from multi-layered medieval 
paintings is generally ambiguous, particularly in the case of metal leaves on bole ground and pigmented coatings as in case study 3 . On the other hand, overpaintings do not necessarily become obvious if the pigments do not contain a characteristic element pattern as in the case study 2 . Here, additional investigation of cross-sections, although destructive, are of considerable help.

\section{Acknowledgements}

The author is indebted to the following persons: Maria Körber carried out the technological investigation and documentation of the painting from Halberstadt. Dr. Andreas Henning made possible the measurements on the painting by Bevilacqua. The instrument for the investigation of both paintings was kindly made accessible by Dr. Stefan Simon from the Rathgen Forschungslabor of the Staatliche Museen Berlin. Those measurements were carried out by Sonja Krug. Babette Hartwieg made possible the measurements on the Barfüsser altarpiece and provided art technological details. Dr. Armin Gross from Bruker AXS provided the instruments and carried out the measurements on that object. The author also wishes to thank Armin Gross for valuable discussion and advice.

Received: October 3, 2008

[1] A. R. Woll, D. H. Bilderback, S. Gruner, G. Ning, H. Rong, C. Bisulca, J. Mass, in Proceedings Materials Issues in Art and Archaeology VII: Materials Research Society Symposium, Nov. 30-Dec. 3, 2004, Boston, Mass., Materials Research Society Symposium Proceedings 2005, 852, 281.

[2] B. Kanngiesser, W. Malzer, A. F. Rodrigues, I. Reiche, Spectrochimica Acta $B$ 2005, 60, 41 .

[3] D. C. Stulik, in Preprints 14th Triennial meeting, The Hague, 12-16 Sept. 2005, ICOM-CC, James \& James, London 2005, p. 556.

[4] Z. Szökefalvi-Nagy, in 'In situ applications of $\mathrm{X}$ ray fluorescence techniques. Final report of a coordinated research project 2000-2003',IAEA-TECDOC-1456, International Atomic Energy Agency (IAEA), Vienna, 2005, p. 127.

[5] V. Villiger, A. A. Schmid, 'Hans Fries. Ein Maler an der Zeitenwende', Hirmer, München, 2001.

[6] L. Dussubieux, S. E. Pinchin, J. Tsang, C. S. Tumosa, in Preprints of the 14th Triennial Meeting, The Hague, 12-16 Sept. 2005, ICOM-CC, 2005, p. 766.

[7] D. Gros, A. Stoll, S. Wülfert, in 'Giovanni Giacometti 1868-1933 Werkkatalog der Gemälde', vol. 2-1, Eds. P. Müller, V. Radlach, Swiss Institute for Art Research, Zurich, 1997, p. 64.

[8] Y. Hayakawa, T. Tsuda, S. Miura, in 'Historische Polychromie: Skulpturenfassung in Deutschland und Japan', Hirmer, München, 2004, p. 393.

[9] Y. Hayakawa, S. Shirono, S. Miura, T. Matsushima, T. Uchida, Powder Diffraction 2007, 22, 126.
[10] H. Bronk, S. Röhrs, A. Bjeoumikhov, N. Langhoff, J. Schmalz, R. Wedell, H.E. Gorny, A. Herold, U. Waldschläger, Fresenius J. Anal. Chem. 2001, 371, 307.

[11] O. Hahn, H.-E. Gorny, Z. f. Kunsttechnologie und Konservierung 2000, 14, 384.

[12] B. Kanngiesser, O. Hahn, M. Wilke, B. Nekat, W. Malzer, A. Erko, Spectrochimica Acta B 2004, 59, 1511.

[13] O. Hahn, D. Oltrogge, H., Bevers, Archaeometry 2004, 46, 273.

[14] O. Hahn, B. Kanngießer, W. Malzer, Studies in Conservation 2005, 50, 23.

[15] S. Röhrs, H. Stege, X-Ray Spectrometry 2004, 33, 396.

[16] K. Matauschek, Restauro 2003, 109, 348.

[17] H. Stege, Z. f. Kunsttechnologie und Konservierung 2004, 18, 121.

[18] O. Hahn, A. Schönemann, Z. $f$. Kunsttechnologie und Konservierung 2004, 18, 29.

[19] J. Bartoll, A. Unger, K. Püschner, H. Stege, Studies in Conservation 2003, 48, 195.

[20] J. P. Sirois, G. Sansoucy, Collection Forum 2001, 17, 49.

[21] K. Anheuser, B. Gnädinger, V. Hubert, K. Hunger, D. Minderd, G. Petrak, M. Rohrbach, G. Teoh, R. Tobler, M. Wörle, Chimia 2007, 61, 743.

[22] H. Stege, O. Hahn, J. Müller, Restauro 2004, 110, 385.

[23] G. Vittiglio, S. Bichlmeier, P. Klinger, J. Heckel, W. Fuzhong, L. Vincze, K Janssens, P. Engström, A. Rindby, K. Dietrich, D. Jembrih-Simbürger, M Schreiner, D. Denis, A. Lakdar, A. Lamotte, Nuclear Instruments \& Methods in Physics Research B 2004, 213, 693.

[24] V. Desnica, M. Schreiner, X-Ray Spectrometry 2006, 35, 280.

[25] D. Jembrih-Simbürger, M. Schreiner, L. Puchinger, C. Hofmann, R. Eichinger, PapierRestaurierung: Mitteilungen der IADA 2004, 5, 26.

[26] D. Jembrih-Simbürger, V. Desnica, M. Schreiner, É. Thobois, H. Singer, K. Bovagnet, Technè 2005, 22, 32.

[27] R. Cesareo, A. Castellano, M. Marabelli, G. Buccolieri, S. Quarta, P. Santopadre, M. Ieole, S. Ridolfi, G.E. Gigante, in 'In situ applications of X-ray fluorescence techniques. Final report of a coordinated research project 2000-2003', IAEATECDOC-1456, International Atomic Energy Agency (IAEA), Vienna, 2005, 151.

[28] G. Gigante, P. Ricciardi, S. Ridolfi, Revue d'archéométrie 2005, 29, 61 .

[29] C. Ricci, I. Borgia, B. G. Brunetti, C. Miliani, A. Sgamellotti, C. Seccaroni, P. Passalacqua, J. Raman Spectrosc. 2004 35, 616.

[30] G. Paternoster, R. Rinzivillo, F. Nunziata, E. M. Castellucci, C. Lofrumento, A Zoppi, A. C. Felici, G. Fronterotta, C. Nicolais, M. Piacentini, S. Sciuti, M Vendittelli, J. Cultural Heritage 2005, 6 , 21.

[31] C. Lin, D. Xunliang, L. Zhiguo, P. Qiuli, C. Xuelian, Spectrochimica Acta B 2007, $62,817$.
[32] H. Dubois, H. Khanjian, M. Schilling, A. Wallert, Z. f. Kunsttechnologie und Konservierung 1997, 11, 228.

[33] M. Petrasch, 'Konservierung und Restaurierung der Tüchleinmalereien des Heiltumsschrankes im Dom zu Halberstadt', Diploma thesis, Hochschule für Bildende Künste Dresden, 2006, vol. 2 and 3.

[34] M. Körber, Z. f. Kunsttechnologie und Konservierung 2008, 22, 41.

[35] K. Helwig, in 'Artists' Pigments', vol. 4, Ed. B. H. Berrie, Butterworth-Heinemann, Washington/London 2007, p. 89.

[36] C. Schölzel, Z. f. Kunsttechnologie und Konservierung 2008, 22, 10. See further contributions in the same issue.

[37] C. Herm, S. Krug, J. Mazurek, M. Schilling, Z. $f$. Kunsttechnologie und Konservierung 2008, 22, 20.

[38] S. Wülfert, 'Der Blick ins Bild', Ravensburger Buchverlag, Ravensburg, 1999.

[39] B. Hartwieg, C. Herm, in ART'05, 8th International Conference on NonDestructive Investigations and Microanalysis for the Diagnostics and Conservation of the Cultural and Environmental Heritage, Lecce (Italy), 15-19 May 2005, CD-ROM 2005, no. 66.

[40] 'Frömmigkeit und Propaganda. Forschungen zu Funktion, Technologie und Stil des Göttinger Barfüßeraltares von 1424', Kolloquium Hannover, 28.-30.09.2006', Niederdeutsche Beiträge zur Kunstgeschichte, special issue, forthcoming.

[41] C. Herm, A. Gross, in 'Frömmigkeit und Propaganda. Forschungen zu Funktion, Technologie und Stil des Göttinger Barfüßeraltares von 1424', Kolloquium Hannover, 28.-30.09.2006, Niederdeutsche Beiträge zur Kunstgeschichte, accepted.

[42] H. Kühn, 'Erhaltung und Pflege von Kunstwerken', 3rd. ed., Klinkhardt \& Biermann, München 2001, p. 51.

[43] E. L. Richter, unpublished report, 2001.

[44] B. A. Gross, U. Waldschläger, in 'ART'05, 8th International Conference on Non-Destructive Investigations and Microanalysis for the Diagnostics and Conservation of the Cultural and Environmental Heritage', Lecce (Italy), 15-19 May 2005, CD-ROM.

[45] D. A. Scott, 'Copper and Bronze in Art', The Getty Conservation Institute, Los Angeles, 2002. 